\title{
Reducing the uncertainty in indirect estimates of extreme flash flood discharges
}

\section{Darren Lumbroso ${ }^{1,2}$ and Eric Gaume ${ }^{1}$}

\author{
${ }^{1}$ Institut Français des Sciences et Technologies des Transports, de l'Aménagement et des Réseaux (IFSTTAR), Centre de Nantes, BP 4129 , 44341 \\ Bouguenais Cedex, France \\ ${ }^{2}$ HR Wallingford, Howbery Park, Wallingford, Oxfordshire OX10 8BA, UK \\ Corresponding author: Darren Lumbroso, d.lumbroso@hrwallingford.com. Eric Gaume, eric.gaume@ifstarr.fr
}

Published in the Journal of Hydrology, Volume 414-415, PP 16-30 (January 2012)

\section{Abstract}

Direct current meter measurements are rarely available for extreme flash floods. Corresponding discharges are generally estimated using so-called "indirect" techniques such as the slope - area method. These methods are based on empirical hydraulic formulae that typically use Manning's equation, and have been calibrated and also widely tested for flow conditions that differ significantly from those encountered during flash floods. Recent work conducted in Europe, as part of the HYDRATE research project and other studies, has shown that the use of these formulae and their associated tabulated roughness values available in current guidance documents, without further verification, can lead to over-estimates of peak discharges in the case of flash floods. After having discussed the limitations of indirect methods based on Manning's formula, the paper illustrates how the uncertainty in indirect discharge estimates can be reduced through the analysis of various types of data that can be collected during post-event surveys and through consistency checks. Based on a review of current literature and on recent flash flood studies, this paper proposes simple guidelines to assist practitioners in estimating extreme discharges during post-event surveys.

\section{Keywords}

flash floods; indirect estimates; Manning's n

\section{Introduction}

In many parts of the world, flash floods are the most destructive natural hazard often resulting in a large amount of damage and fatalities. Approximately 40\% of the flood-related deaths in Europe between 1950 and 2006 were linked to flash floods (Barredo, 2007). The lack of data on flash floods (Marchi et al, 2010), and in particular the lack of accurate discharge estimates, can often provide an obstacle to improvements in flood forecasting, warning, planning and emergency management. The estimation of peak flash flood discharges in ungauged catchments can be likened to solving a jigsaw for which an unknown number of pieces are missing, others are damaged, and some belong to a different puzzle (CEH, 1999).

Flash floods are caused by short duration, high intensity, localized rainfall events. They differ from most other fluvial floods in that the lead time for warnings is generally very limited (.e.g. often much less than two hours). They usually occur on catchments draining less than $1,000 \mathrm{~km}^{2}$ with response times of a few hours or 
less (Borga et al, 2008; Gaume and Borga, 2008). Direct current meter measurements during the peak of the floods are often impossible to conduct for safety and technical reasons (Fukami et al, 2008). There is also normally insufficient time to organize field measurements during the events. Ungauged watercourses are often not accessible without incurring significant risks, preventing flow measurements, even with the use of non-contact methods. If there is a water level gauge in place, which is not damaged by the flood, it can provide an accurate measurement of the level reached by the water; however, for other cross-sections the maximum level has to be determined from flood marks. These levels generally far exceed the justifiable range of any stage - discharge relationship that may exist at the site (Gaume and Borga, 2008).

As a result of these limitations most extreme flash flood discharge values are estimated using "indirect" hydraulic methods, based on (a) various solutions of the one-dimensional, gradually-varied, steady-state flow equations for open channels or in some cases (b) weir and culvert equations. Apart from techniques based on a critical flow assumption, all these methods include empirical head-loss formulae. Manning's equation is generally at the heart of the type (a) methods and the most commonly used method for indirect discharge estimations: the slope-area method (Benson and Dalrymple, 1967; Costa and Jarrett 2008; Webb and Jarrett, 2002) or its simplified form based on a uniform flow assumption, the slope-conveyance method.

A wide array of experience has been gained over the past century on the use of the Manning's equation and the link between the characteristics of different river reaches and the possible values of their Manning's $n$ roughness. This experience has been summarized in various reference texts and manuals (e.g. Chow, 1959; Barnes, 1967; Limerinos, 1970; Hicks and Mason, 1998). However, this experience mostly corresponds to flow conditions that enable direct current meter measurements and that are significantly different from the conditions encountered during extreme flash floods where there are usually high velocities $(>1.5 \mathrm{~m} / \mathrm{s})$ in relatively narrow and steep streams. This is illustrated in the second part of the paper.

This paper poses several questions. Is it reasonable to extrapolate an empirically based head-loss formula, such as Manning's equation, based on observations from low or moderate flow conditions to extreme flash flow conditions? And if the relationship between the head-loss and the characteristics of the flow is kept the same, is it reasonable to think that the value of its main controlling parameter, the Manning's $n$ roughness coefficient, does not vary with the discharge or mean velocity of the flow? Some authors (Jarrett 1985; Jarrett 1987; Trieste, 1992; Soto and Madrid-Aris, 1994) suggest that the use of traditional roughness values for rivers affected by flash flood may lead to significant over-estimates of peak discharges. They argue that the Manning's $n$ roughness coefficient should be increased when dealing with extreme flash floods to obtain "reasonable" estimates of discharges. Recent post-flood event surveys conducted by the authors in Europe, as well as the re-analysis of published estimates presented in this paper also lead to the same conclusion.

This paper provides guidelines, based on recent work, for reducing uncertainty in estimates of extreme flash flood discharges, and particularly for limiting the probability of significant over-estimates of peak flows. The paper is structured in three parts. It commences with the historical background to Manning's equation, which is often overlooked by present day practitioners; however, it is important to revisit the derivation of the equation to be able to understand fully its possible limitations. The paper then illustrates how various sources of information can be used in a post-event survey to evaluate the credibility of a first estimate of discharge in a given river reach based on a standard hydraulic method, typically the slope-area method. Guidelines for the estimation of extreme flash flood discharges are proposed at the end of the paper. Past-studies are reanalyzed in the light of these guidelines and their possible impact on the existing world maximum observed flood discharge envelope is discussed. 


\section{Manning's equation - its origins, use and limitations}

\subsection{The origins of Manning's equation}

The so-called Manning's equation ${ }^{1}$ (equation 1 ) is one of numerous empirical friction-loss formulae that was proposed for open channel flow in the eighteenth and nineteenth centuries. During this period formulae were proposed by: Du Buat (1786); Eyelwein (1814); Weisbach (1845); St. Venant (1851); Neville (1860); Darcy and Bazin (1865); Gauckler (1867); and Ganguillet and Kutter (1869).

$$
V=C R^{\frac{2}{3}} S^{\frac{1}{2}}
$$

In Manning's equation " $V$ represents the average cross-sectional velocity in seconds for all measures of lengths, $C$ is a coefficient which varies with the nature of the bed, $S$ is the sine of the angle of inclination of the surface; $R$ is "the mean radius" or "mean hydraulic depth" (which is found by dividing the area of the channel by the length of the perimeter in contact with the fluid)" (Manning, 1891).

Equation 1 was not the form preferred and promoted by Manning in his publication (Manning, 1891), but a simplified version of it. The value of the exponent of $R$ was fixed after calibrating equation 1 using data from experiments on artificial channels undertaken by Darcy and Bazin in 1865. The exponent appeared to vary with the shape and roughness of the channels, $2 / 3$ being an average value. Probably because of its simplicity, equation 1 caught the attention of many hydraulic engineers and was already being referenced in textbooks by the end of the nineteenth century using Manning's name. The publication of King's book in 1918, entitled the "Handbook of Hydraulics", seems to have led to the widespread use of Manning's formula (Fischenich, 2000). According to Chow (1959), equation 1 strongly supported by Lindquist (1933), progressively became the standard equation to compute friction losses in the first part of the twentieth century.

The Manning equation used today (equation 2), given below, differs from the original version.

$$
V=\frac{R^{\frac{2}{3}} S_{f}^{\frac{1}{2}}}{n}
$$

The roughness parameter $\mathrm{n}$ appears as the denominator; in non-uniform flow conditions, the friction slope $\mathrm{S}_{\mathrm{f}}$ is not the slope of the water surface: according to the Bernoulli formula $S_{f}=S+\frac{\partial}{\partial x}\left(\frac{V^{2}}{2 g}\right)$ and finally, the slopes are computed as the tangents and not the sines of the angles.

Often in estimating Manning's $n$ only streambed and bank characteristics are considered. In reality Manning's $\mathrm{n}$ depends upon a number of factors and forms of energy losses as shown in Figure 1, as a result Manning's n, especially after large floods, can vary significantly with flow conditions.

\footnotetext{
${ }^{1}$ In fact, equation (1) was first proposed by the French engineer Gauckler in 1867 and a similar formulation had also been proposed by the German scientist Hagen in 1881. It seems that Manning was unaware of Gauckler's work.
} 


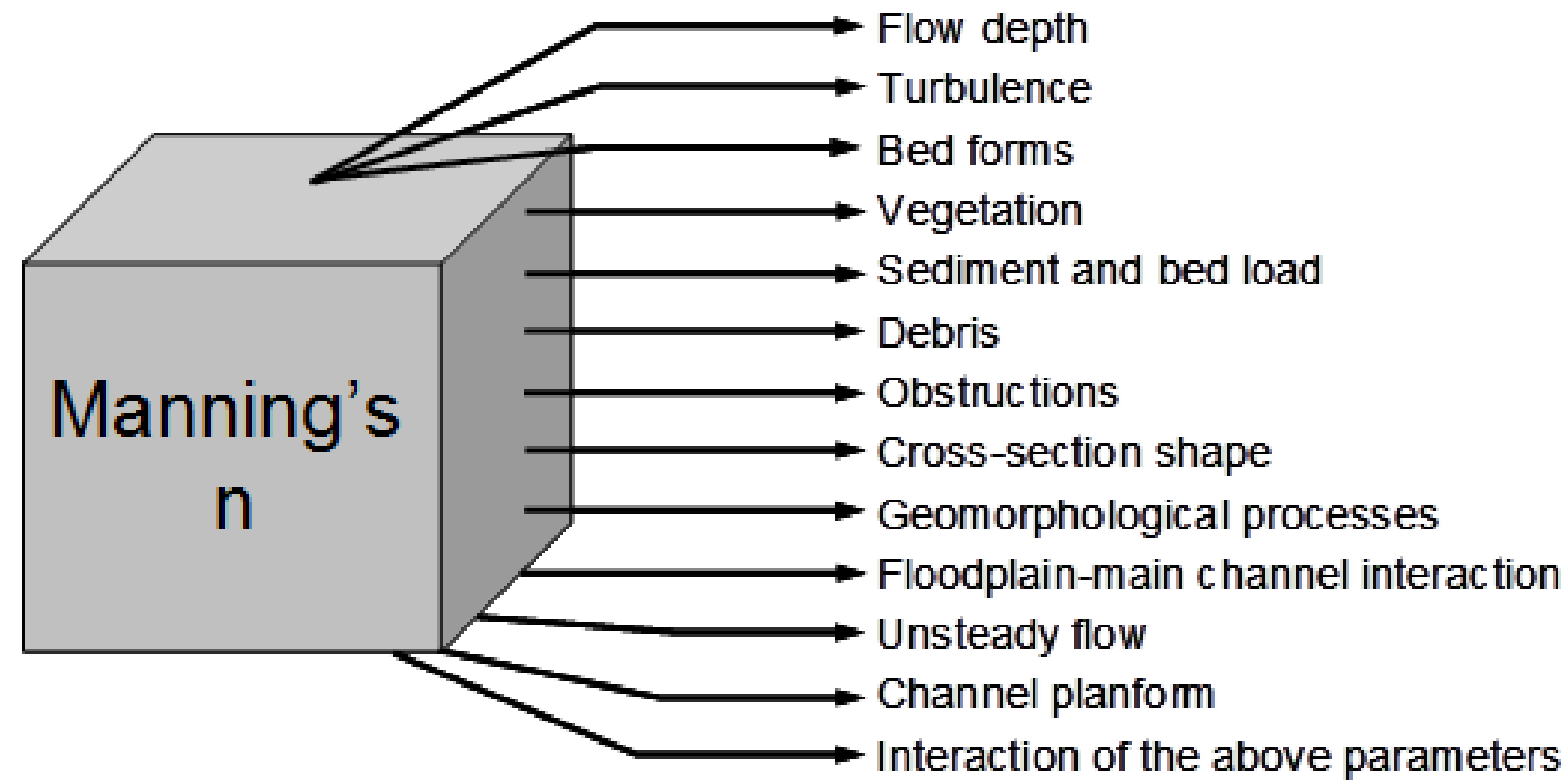

(Source: Adapted from Trieste and Jarrett, 1987)

Figure 1: The parameters that need to be taken into account by Manning's $n$

\subsection{Estimation of Manning's $n$}

The Manning's equation is a simple, empirical formula that has been used successfully on a wide range of engineering projects and studies worldwide over the past century. The success of the equation is demonstrated by the fact that it remains the cornerstone of working practice in the fields of flood estimation and river hydraulics, despite several scientific critiques that it oversimplifies the complexities of the energy losses in rivers (Whatmore and Landström, 2009; Knight et al, 2010). It is also often encountered as a required input value by users of one dimensional hydraulic modelling software because Manning's equation is the standard numerical solution relating water levels, friction slopes, velocities and channel characteristics (Whatmore and Landström, 2009).

There are a number of reference texts that are commonly used by practitioners to estimate Manning's $\mathrm{n}$. Chow's "Open Channel Hydraulics" (1959) presents a variety of photographs of watercourses and drainage channels in the USA with associated $n$ values. These are mainly based on publications by Ramser (1929) and Scobey (1939) produced for the US Department of Agriculture that provided estimated values of Manning's n, computed from current meter measurements, for a number of drainage channels. In 1967 Barnes produced a guide entitled "Roughness characteristics of natural channels". Reach-wise Manning's $n$ values were computed for 50 watercourses from across the USA and were presented along with colour photographs, sketches of the cross sections, and site descriptions (Barnes, 1967).

Since 1967 there have been various publications that have added to Barnes' visual approach for determining Manning's $n$ values in natural streams. For example, Hicks and Mason (1998) presented Manning's n values for 78 watercourses in New Zealand; Arcement and Schneider (1989) for floodplain channels; Coon (1998) 
for natural stream channels with vegetated banks; Gillen (1996) for streams in west-central Florida; Jarrett (1985) for high-gradient streams in Colorado; Phillips and Ingersoll (1998) for natural and constructed channels in arid and semi-arid environment in Arizona; and information has also been compiled for Manning's $n$ values for watercourses in Australia (Land and Water Australia, 2009).

\subsection{The use and limitations of Manning's equation to estimate extreme flood discharges}

Flash floods are generally defined as events that develop in less than six hours after a rainfall event and create hazardous situations for people and extensive damage to property (Knocke and Kolivras, 2007). Flash floods can occur in the upper reaches of catchments, wadis, canyons, urban areas and in engineered channels. In many cases the flow is far from uniform, the Froude number is sometimes close to one and the mean velocity of the flow is high. Work undertaken by Jarrett $(1985,1987)$ and Soto $(1994)$ has indicated that for these rivers the use of a traditional estimation of roughness can lead to an underestimation of the Manning's $n$, resulting in an overestimate of the flow velocity and as a consequence the peak flash flood discharge. Flood flow conditions, and more especially flash flood flows, are not well represented in the data sets used to establish Manning's $n$ values in guidance documents. As a consequence the applicability of empirically derived flow resistance relationships, such as Manning's equation to estimate extreme flows need to be validated using other information.

As part of a European Commission research project, called Hydrometeorological Data Resources and Technologies for Effective Flash Flood Forecasting (HYDRATE), peak flow data was collated for a number of past flash floods in six European countries via post-flood surveys that used indirect methods (HYDRATE, 2008). These events include floods that took place in France and Slovenia in 2002 and 2007, some of which have an estimated return period well in excess of 1 in 100 years (Gaume et al, 2009). The HYDRATE flood surveys indicated that utilising roughness coefficients based on guidance documents resulted in overestimates of peak flash flood discharges and as a consequence the roughness values used were increased.

In 2008 Costa and Jarrett carried out an evaluation of selected extraordinary floods in the USA. These floods determine the envelope curve of maximum floods documented in the USA (Costa and Jarrett, 2008). The discharges of almost all of these floods were estimated using indirect methods. Costa and Jarrett (2008) appeared to have used Manning's $n$ roughness values based on guidance documents.

The next three sections discuss the velocity, Manning's $n$ and Froude number distributions for the HYDRATE flood events, the extraordinary floods in the USA and data on which many of the guidance documents are based.

\subsubsection{Comparison of the velocity distributions}

Figure 2 shows distributions of mean cross-sectional velocities for the following:

- "Guidance document" data based on current-meter measurements, the results of which have been used to inform the estimates of Manning's $n$ that appear in texts such as: Chow, 1959; Barnes, 1967; Hicks and Mason, 1998 plus several others (see Figure 2)

- Indirect estimates of velocities for extraordinary flash floods that took place in France and Slovenia in 2002 and 2007 compiled for the HYDRATE research project (HYDRATE, 2008) 
- Indirect estimates of velocities for an evaluation of US extraordinary floods, several of which were flash flood events (Costa and Jarrett, 2008).

The three velocity distributions in Figure 2 illustrate just how different the estimated values of peak mean cross-sectional velocities are for extreme floods to the measured velocities used to inform the values of Manning's $\mathrm{n}$ that appear in the guidance documents. The distributions in Figure 2 shows that in the guidance documents less than $0.2 \%$ of the mean velocity measurements exceeded $3.5 \mathrm{~m} / \mathrm{s}$. In contrast, $25 \%$ of the indirectly estimated mean cross-sectional velocities in France and Slovenia, and $75 \%$ of those in US extraordinary flood data set exceeded $3.5 \mathrm{~m} / \mathrm{s}$.

Figure 2 also shows that there is a significant difference between the estimated, peak, mean velocities estimated for the HYDRATE and US data. This difference is primarily based on the choice of roughness distribution. This raises the question, posed at the beginning of the paper, as to whether empirical roughness values in the guidance documents that are based on relatively moderate flows and velocities can be used in indirect estimates of extreme flash flood flows and whether the approaches that should be used to estimate extreme flash floods.

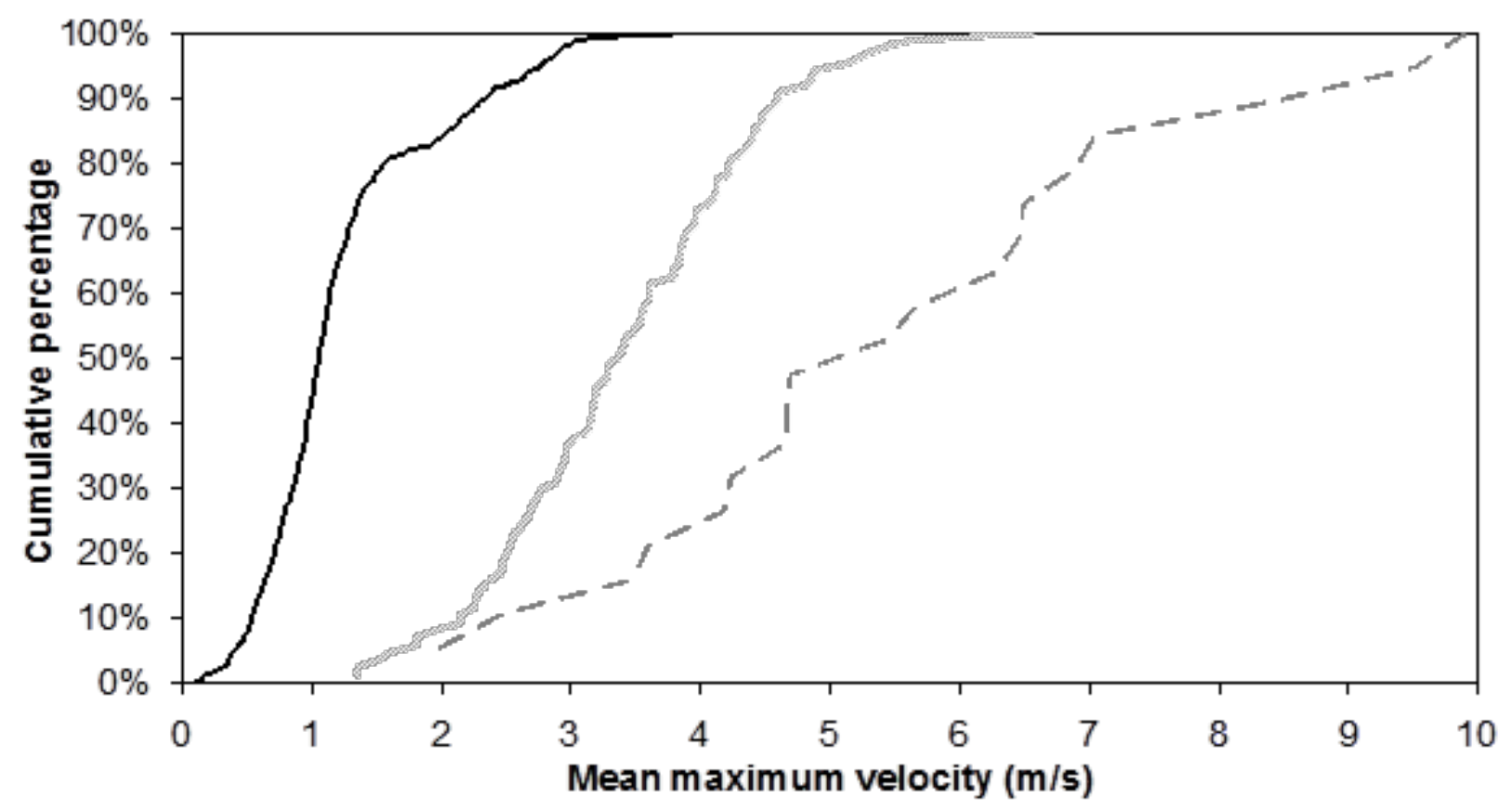

- Guidance documents - - US extraordinary floods $\quad$ HYDRATE data: France and Slovenia

(Sources of data: Barnes, 1987; Chow, 1959; Cone et al, 1914; Costa and Jarr ett, 2008; Environment Agency, 2002; Fasken, 1963; Hidks and Mason, 1998; HYDRATE, 2008; Land and Water Australia, 2009, Ramser, 1929, Scobey, 1939; Scong, 2009, Spreafico et al, 2001)

Figure 2: Distributions of the mean maximum cross-sectional velocity for extraordinary floods in the USA; France and Slovenia; and for a range of guidance documents 


\subsubsection{Comparison of the roughness distributions}

Figure 3 shows distributions of Manning's $n$ for the three data sets shown in Figure 2. It can be seen that the Manning's $\mathrm{n}$ used in the indirect methods to estimate extraordinary floods in the USA follows a similar distribution to the Manning's $\mathrm{n}$ distribution of the guidance documents. However, the roughness coefficients used to estimate extreme flood floods in the Europe were generally much higher than the roughness values used in the USA and those found in the guidance documents. For the guidance documents and US extraordinary floods only $25 \%$ and $11 \%$ respectively of the computed Manning's n were equal to or exceeded a value of 0.05 . However, for the estimates of extreme flash floods in Europe $67 \%$ of the roughness coefficients used equalled or exceeded a value of 0.05 .

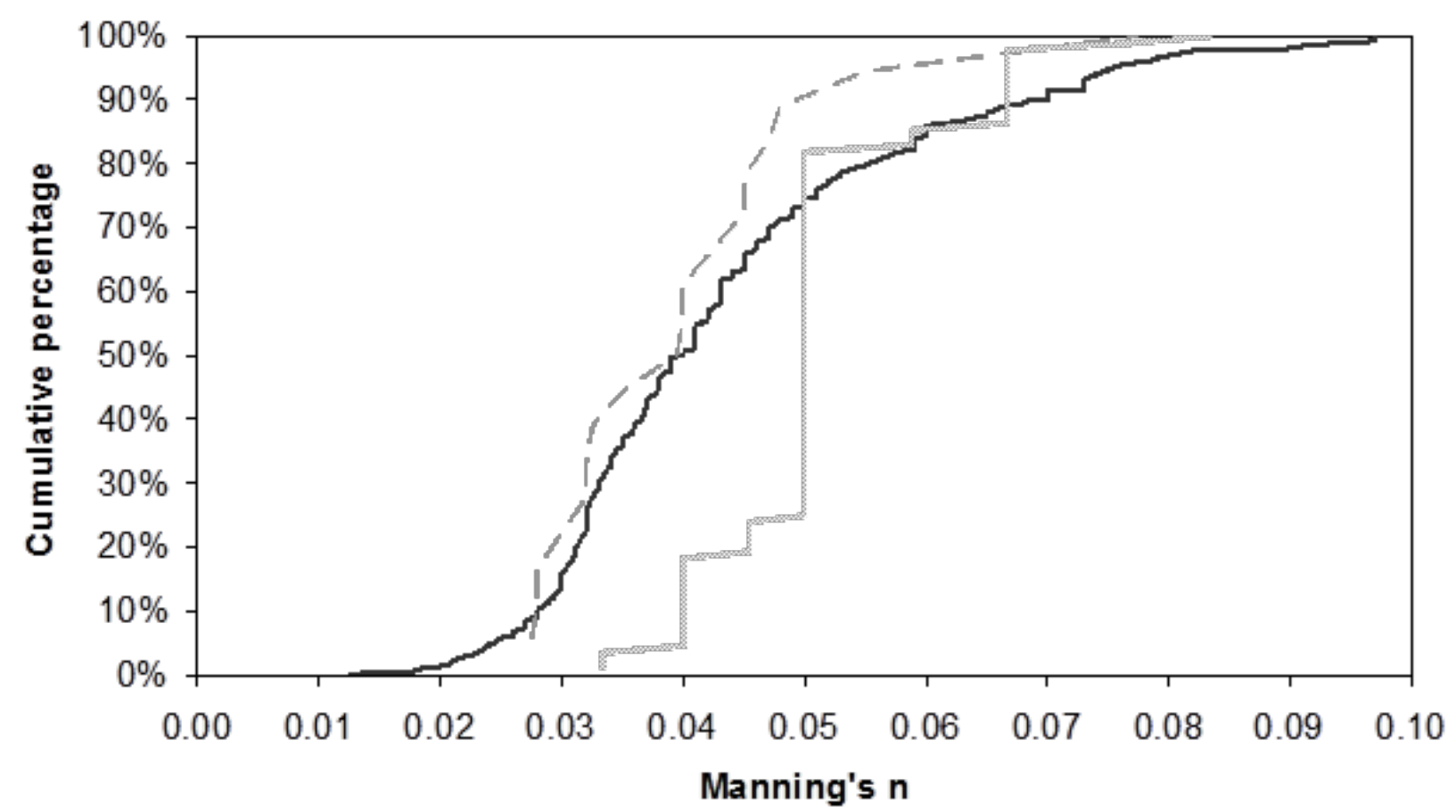

- Guidance documents - -US extraordinary floods w HYRATE data: France and Slovenia

(Sources of data: Barnes, 1987; Chow, 1959; Cone et al, 1914; Costa and Jarrett, 2008; Environment Agency, 2002; Fasken, 1963; Hioks and Mason, 1998; HYDRATE, 2008; Land and Water Australia, 2009; Ramser, 1929, Scobey. 1939; Scong, 2009, Spreafico et al, 2001)

Figure 3: Distributions of Manning's n for extraordinary floods in the USA; France and Slovenia; and for a range of guidance documents

\subsubsection{Comparison of the Froude number distributions}

Figure 4 shows the distributions of Froude number for the three data sets. For the guidance documents and HYDRATE flood data sets only $7 \%$ and $12 \%$ respectively of the computed mean cross-sectional Froude numbers were equal to or exceeded a value of one. However, for the US extraordinary flood data $47 \%$ of the values equalled or exceeded a Froude number of one.

Several investigators have argued that supercritical flow (i.e. flow with a Froude number $>1$ ) cannot be sustained over long reaches (i.e. >20 m) in natural channels (Jarrett, 1984, 1987; Grant, 1997; Tinkler, 
1997). Hydraulic modelling studies of dam breaks in the USA have also indicated that for the average crosssection, the Froude number of the flow is generally less than one (Blanton, 1977; Fread, 1977; Trieste, 1992; Yochum et al, 2008). These researchers agree that supercritical flow appears in small reaches of highgradient channels, but quickly changes back to sub-critical because of extreme energy dissipation and turbulence due to obstructions and shear stress as a result of the difference in friction between the free surface and the channel bed. Bathurst et al. (1979) also showed that additional energy is consumed when bed material is transported. Jarrett and Wahl's data indicate that even though few situations revealed supercritical flow, there were a significant number of flows in natural channels with Froude numbers between 0.7 and 1.0 (Jarrett, 1984; Wahl, 1993). In the case of the HYDRATE flow estimates $45 \%$ had a Froude number greater than 0.7 . The importance of assessing Froude number when estimating flash flood flows using indirect methods is discussed in section three of the paper.

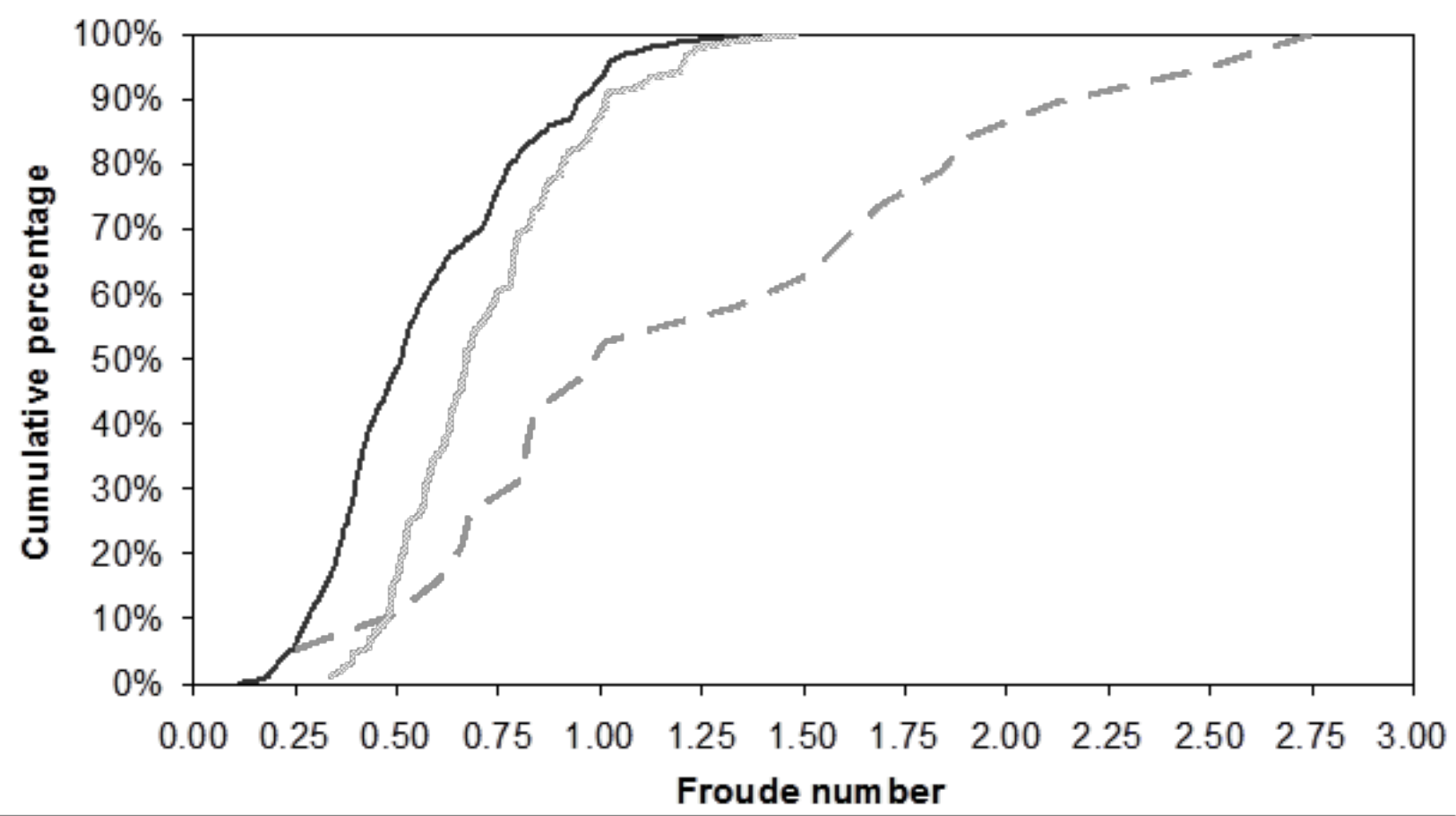

- Guidance document data - US Extraordinary floods $\quad$ HYDRATE data: France and Slovenia

(Sources of data: Barnes, 1967; Chow, 1959; Cone et al, 1914; Costa and Jarrelt, 2008; Environment Agency, 2002; Fasken, 1963; Hidks and Mason, 1998; HYDRATE, 2008; Land and Water Australia, 2009; Ramser, 1929, Scobey. 1939; Scong, 2009, Spreafico et al, 2001)

Figure 4: Distributions of Froude number for extraordinary floods in the USA; France and Slovenia; and for a range of guidance documents

\subsubsection{Comments on the distributions}

The three distributions shown in Figures 2, 3 and 4 indicate that there appears to be "two schools of thought" regarding the values of roughness coefficients to use in indirect methods to estimate extreme flood flows. In Costa and Jarrett's work (2008) it would appear that the guidance document values of roughness coefficients are considered to be acceptable. This results in relatively high velocities and Froude numbers. In Europe, for the HYDRATE project, indirect estimates of extreme flash flood flows were made using roughness 
coefficients that were higher than those suggested in the guidance documents. This results in lower velocities and Froude numbers.

Research has shown the Manning's $n$ value in most watercourses decreases with an increase in stage and discharge (Hicks and Mason, 1998; Fisher and Dawson, 2003). However, in this paper we postulate that for extreme flash floods Manning's n may not evolve in this manner, even in channels with limited overbank flow, but that roughness actually increases as the stage and velocity increase. Possible explanations for this include the increased roughness of the banks owing to denser vegetation, but also as a result of an overall increase in the turbulence and energy dissipation with the increased average velocity as is observed in pressure flows. There are also potentially large components of flow resistance associated with changes in bed forms during a flood, as well as increased flow resistance created by free surface instabilities and hydraulic jumps especially at low values of relative submergence of obstacles both in the bed and the bank of the watercourse (Grant, 1997; Tinkler, 1997).

Most of the widely used indirect discharge methods assume quasi-steady one dimensional flow (Benson and Dalrymple, 1967; Dingman, 2008). This often does not reflect reality during extreme flows and hence there is no reason to think that Manning's roughness coefficients verified for relatively tranquil hydraulic conditions should be still valid for extreme flows. As a consequence indirect estimates of extreme flash flood discharges cannot necessarily only rely on roughness values based on the currently available literature. This also means that when using indirect methods additional information and validation exercises are required to confirm that the estimated discharge values are "reasonable". The third part of this paper builds on the ideas introduced here and provides guidance for validating indirect extreme flood flow estimates.

\section{Guidance for validating and reducing the uncertainty in indirect extreme flood flow estimates}

The first part of this paper has shown that there appear to be different views on the value of Manning's $n$ roughness to use when estimating extreme flows indirectly. As a consequence of this it is important that indirect flood flow estimates are validated to assist in reducing the uncertainties. This second part of the paper provides guidance using field data to assist practitioners in achieving this goal as follows:

1. Use of rainfall data and extreme peak flood flow envelopes

2. Estimates of maximum mean velocities and the use of simple rainfall-runoff and routing models

3. Use of pictures and films of the flood event

4. Estimation of the mean Froude number

\subsection{Use of rainfall data and extreme peak flood flow envelopes}

Comparing peak discharges estimated via indirect methods with available rainfall data and peak flood flow envelopes should be the first step in validating indirect flow estimates. This is discussed below.

\subsubsection{Comparing estimated discharges with the estimated rainfall intensity}

Indirect flood estimates should be checked for consistency against any available rainfall data for the catchment. The reductions over the past decade of the uncertainties associated with rainfall intensities estimated by radars means that if available these intensities can be used to assist in verifying any estimates that are made of peak flood flows, although it is important to bear in mind that radar rainfall estimation can be 
subject to errors caused by various factors ranging from instrument issues to the high complexity and variability in the relationship of the measurement to precipitation parameters (Hossain et al, 2004).

A simple validation exercise can be done by applying the rational method, assuming $100 \%$ runoff, and comparing the specific peak discharge (in $\mathrm{mm} /$ hour) with the maximum rainfall intensity for the flood event over a time period for the estimated time of concentration for the catchment. The rational method is an empirical relationship normally used on small urban catchments (e.g. $<1 \mathrm{~km}^{2}$ ) that generally leads to conservatively high peak flow estimates (California Department of Transportation, 2009). However, it provides another quick and simple validation tool. Unless the flood event has been a result of dam break, or the failure of another type of structure where a large volume of water is stored, the ratio of the discharge to the rainfall should always be less than one. A ratio of greater than one points to an overestimate of the discharge and the need for further investigations.

For example, an extreme flash flood event at Boscastle in the UK in 2004 produced an estimated peak discharge of $180 \mathrm{~m}^{3} / \mathrm{s}$ from a $20 \mathrm{~km}^{2}$ catchment (Roca and Davison, 2010). The average slope of the watercourse is steep, approximately $0.045 \mathrm{~m} / \mathrm{m}$. The time of concentration for the catchment is approximately one hour. The maximum unit discharge for the catchment is $9 \mathrm{~m}^{3} / \mathrm{s} / \mathrm{km}^{2}$ equivalent to a maximum rainfall intensity of approximately $32 \mathrm{~mm} /$ hour. Estimates of hourly rainfall intensities for the 2004 event are in the region of $60 \mathrm{~mm} /$ hour to $80 \mathrm{~mm} /$ hour (Golding, 2005). The ratio of the peak flow to the maximum hourly rainfall was between 0.40 and 0.53 . This appears to be reasonable for this event.

Table 1 presents examples of peak flash flood flows that have been estimated using indirect methods and which do not appear to be consistent with the observed maximum rainfalls. In the case of the Bronco Creek, assuming a mean flow velocity of $3 \mathrm{~m} / \mathrm{s}$ to $5 \mathrm{~m} / \mathrm{s}$ on the catchment and a maximum length of travel of $10 \mathrm{~km}$, the time of concentration would be between 30 minutes and one hour. The estimated peak discharge would require a mean spatial rainfall intensity over the $49 \mathrm{~km}^{2}$ catchment almost twice as high as the maximum observed rainfall intensity over 0.75 hours. Although such a maximum rainfall intensity is not impossible, it would appear unlikely. This consistency test indicates a possible over-estimation of the peak discharge which is in accordance with the conclusion that House and Pearthree reached when they re-estimated the peak flow as being between 750 and $850 \mathrm{~m}^{3} / \mathrm{s}$ (House and Pearthree, 1995). 
Table 1: Comparison of peak flash flood flows based on indirect methods with estimated rainfall intensities for selected examples

\begin{tabular}{|l|l|l|l|l|l|}
\hline & Date & $\begin{array}{l}\text { Catchment } \\
\text { area } \\
\left(\mathrm{km}^{2}\right)\end{array}$ & $\begin{array}{l}\text { Peak } \\
\text { flow } \\
\left(\mathrm{m}^{3} / \mathrm{s}\right)\end{array}$ & $\begin{array}{l}\text { Unit } \\
\text { discharge } \\
(\mathrm{mm} / \mathrm{hour})\end{array}$ & $\begin{array}{l}\text { Estimated rainfall } \\
\text { intensity }(\mathrm{mm} / \mathrm{hour})\end{array}$ \\
\hline $\begin{array}{l}\text { Las Piedras, } \\
\text { Puerto Rico }\end{array}$ & 6 September 1960 & 17.8 & 816 & 165 & $\begin{array}{l}\text { Less than } \\
165 \mathrm{~mm} / \mathrm{hour}\end{array}$ \\
\hline $\begin{array}{l}\text { Rubí Torrent, } \\
\text { Spain }\end{array}$ & 25 September 1962 & 24.3 & 1,750 & 259 & $\begin{array}{l}\text { Between } 140 \text { and } \\
180 \text { mm within three } \\
\text { hours }\end{array}$ \\
\hline $\begin{array}{l}\text { Bronco Creek near } \\
\text { Wikieup, Arizona }\end{array}$ & 18 January 1971 & 49.2 & 2,080 & 152 & 89 mm in 0.75 hours \\
\hline
\end{tabular}

Source: Barnes and Bogart, 1961, Costa, 1987, López Bustos et al, 1964

For the other two flow estimates in Table 1, in each case, the estimated peak discharges would have required that the rainfall to have fallen homogeneously over the catchments for a reduced duration corresponding to the estimated time of concentration of the catchments as follows:

- $124 \mathrm{~mm}$ over 45 minutes for Las Piedras, Puerto Rico i.e. a rainfall intensity of $165 \mathrm{~mm} / \mathrm{hour}$. Information in Barnes and Bogart indicates that the maximum rainfall intensity for this event was probably considerably less than $165 \mathrm{~mm} /$ hour (Barnes and Bogart, 1961)

- $259 \mathrm{~mm}$ over an hour for the Rubí Torrent in Spain. The maximum observed rainfall intensity was between 140 and $180 \mathrm{~mm}$ within three hours (López Bustos et al, 1964)

The above examples where indirect estimates of peak discharge appear to exceed or are close to maximum rainfall values indicate they should be treated with caution and additional evidence gathered to help confirm the flow value.

\subsubsection{The use of extreme peak flood flow envelopes}

The relationship between peak flood flow discharge and catchment area is widely documented (see Sutcliffe, 1978; Farquharson et al, 1992, Centre for Ecology and Hydrology, 1999 and many others). In many parts of the world, envelope curves are used to relate maximum observed floods to the catchment area. The specific peak flood discharge per unit area of the catchment generally increases with a decrease in the area drained. This assumption has been found to hold true, especially for extreme flood events.

In 2003 the International Association of Hydrological Sciences (IAHS) produced a document detailing the world's maximum observed floods, together with a maximum observed flood envelope. Herschy, who compiled the data, proposed that the maximum observed floods per unit area $\mathrm{Q}_{\mathrm{u}}$ in $\mathrm{m}^{3} / \mathrm{s} / \mathrm{km}^{2}$ could be related to the catchment area $\mathrm{A}$ in $\mathrm{km}^{2}$ by:

$Q_{u}=500 A^{-0.57}$ for catchment areas of greater than $100 \mathrm{~km}^{2}$

$Q_{u}=100 A^{-0.2}$ for catchment areas of less than $100 \mathrm{~km}^{2}$

(Herschy, 2002; IAHS, 2003) 
Gaume at al, 2009 and Marchi et al, 2010 proposed a European envelope curve based on data collated as part of the HYDRATE project of the following form:

$Q_{u}=97 A^{-0.4}$

Figure 5 shows the World Catalogue of Maximum Floods and European flash flood envelope curves together with the US extraordinary flood data; World Maximum Observed Flood Catalogue data and extraordinary flash flood data from the HYDRATE project (HYDRATE, 2010).

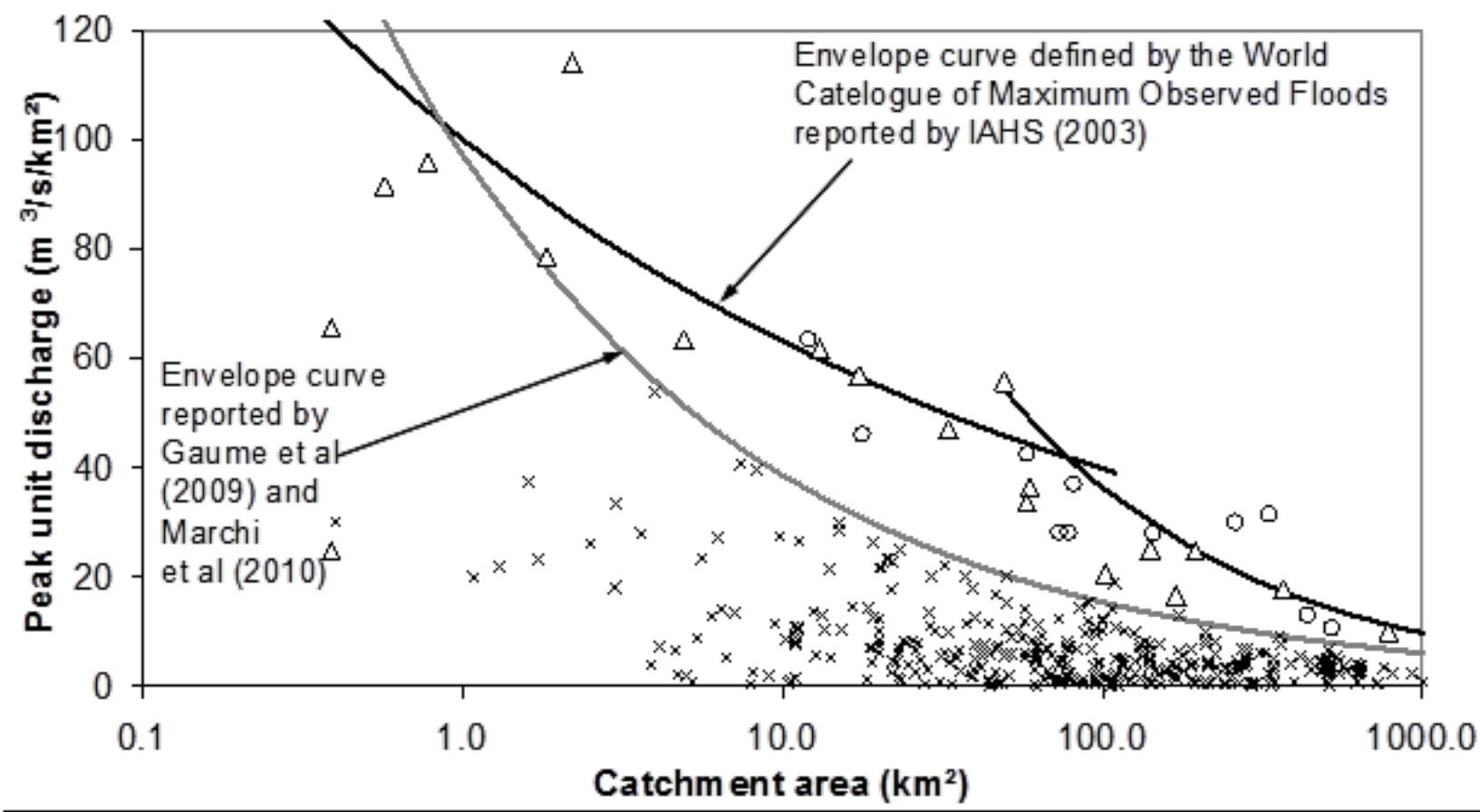

$\Delta$ US extraordinary floods $\times$ European extraordinary flash floods $\circ$ World maximum observed floods

(Sources of data: Costa and Jarrett, 2002; Gaume, 2009; Herschy, 2002; IAHS, 2003; HYDRATE, 2008; Marchi et al, 2010)

Figure 5: Maximum catalogue of world observed floods and European flash flood envelope curves

Where flash flood flows per unit area estimated by indirect methods are found to be high (i.e. greater than values suggested by the above envelope curves) corroborating evidence should be sought either in the form of rainfall-runoff modelling and/or hydraulic modelling to ensure that the peak flow has not been overestimated. This is discussed below.

\subsection{Estimates of the times of travel and mean velocities}

Many practitioners estimate the discharge directly without giving any thought to the times of travel of the flood wave and the values of mean, maximum, cross-sectional velocities associated with their estimates. In many watercourses prone to flash flooding the mean velocity rarely exceeds $3 \mathrm{~m} / \mathrm{s}$ and velocities above 6 $\mathrm{m} / \mathrm{s}$ are extremely unlikely as shown in Figure 2 . For some previous flash flood estimates in the Europe and USA mean velocities of around 20 m/s have been calculated (Aldridge, 1978; López Bustos et al, 1964). Velocities of this order would lead to possibly the largest known magnitude of stream power for a flood 
(Baker and Costa, 1987). It is important that practitioners have a good idea of what the characteristic velocity of a flash flood is.

Evidence from the field of extreme mean cross-sectional velocities, (i.e. $>5 \mathrm{~m} / \mathrm{s}$ ) may point to a case of "debris" rather than "water" flow. Post-flood indirect measurement techniques to back-calculate flood magnitudes are not valid for debris flows (USGS, 2005). In water flow the amount of suspended sediment is not sufficient to substantially affect how the water behaves and Newtonian fluid properties are preserved. The water may appear very muddy but most of the suspended sediment is transported near the bed. Flow behaviour of debris flows, in contrast, is significantly controlled by entrained sediment with the sediment and water mixture becoming a slurry, similar to wet concrete (USGS, 2005). In 2005 the USGS produced a simple guide that can be used to help practitioners distinguish between debris flows and floods from field evidence (USGS, 2005). Typical mean velocities for debris flow have been found to be between $5 \mathrm{~m} / \mathrm{s}$ and 20 m/s (Arattano and Marchi, 2005; Julien and Paris, 2010; Prochaska et al, 2008). Costa also provides details on the rheology of different types of flows and the geomorphological changes that occur after a flash flood that can help distinguish fluid flow from debris flow (Costa, 1988).

\subsubsection{The characteristic velocity of the flash flood process}

The HYDRATE project carried out research into the characterisation of extreme flash floods in Europe. As part of the research Marchi et al (2010) analysed data from 60 flash floods that occurred on catchments throughout Europe. Much of the flood data used in the analysis can be considered to be extraordinary in terms of their severity. In terms of the rainfall or peak discharge many of the events used had return periods exceeding 500 years and in some cases 1000 years. The extraordinary events used included: Fella, Italy in 2003 (Norbiato et al, 2007); Boscastle in the UK, 2004 (Roca and Davison, 2010); Kamp in Austria, 2002 (Ulbrich et al, 2003); Mala Svinka in Slovakia, 1998 (Miklanek et al, 2004); Aude in France, 1999 (Gaume et al, 2004); Weisseritz River in Germany, 2002 (James et al, 2004) and the Gard Region of France, 2002 (Gaume et al, 2009)

For these catchments Marchi et al (2010) estimated that the mean average distance to the catchment outlet to each point in the catchment, $L$ in $\mathrm{km}$ ), was related to the catchment area $A$ in $\mathrm{km}^{2}$ by Equation 6 .

$$
L=0.867 A^{0.551} \mathrm{R}^{2}=0.88
$$

Marchi et al, 2010 also computed the lag time for 50 of the 60 cases for the catchments subject to flash flooding. Marchi defined the lag time as the duration between the centroid of the rainfall hyetograph and the time of the peak discharge of the resulting flow hydrograph. For 37 of the 50 cases the lag time was found to be less than 6 hours a threshold often used to distinguish flash floods from plains floods (Georgakakos, 1986). A relationship between lag time and catchment area has been proposed by Marchi et al (2010), based on the lower bounded curve that encloses all the lag times as follows:

$$
T_{L}=0.08 A^{0.55} \text { for } \mathrm{A} \leq 350 \mathrm{~km}^{2}
$$

1.10

$T_{L}=0.003 A$ for $\mathrm{A}>350 \mathrm{~km}^{2}$

Where $T_{L}$ is the lag time in hours and $A$ is the catchment area in $\mathrm{km}^{2}$

Marchi et al used Equations (7) and (8) to show that the characteristic velocity of the flash flood process does not exceed $3 \mathrm{~m} / \mathrm{s}$ for catchment areas less than $350 \mathrm{~km}^{2}$. This "characteristic velocity of the flash flood process" (for catchments less than $350 \mathrm{~km}^{2}$ ) and is related to the celerity with which the flood wave moves 
through the catchment (Marchi et al, 2010). For catchments larger than $350 \mathrm{~km}^{2}$ this characteristic velocity will also be less than $3 \mathrm{~m} / \mathrm{s}$. The characteristic velocity of the flood waves estimated by Marchi is shown in Figure 6.

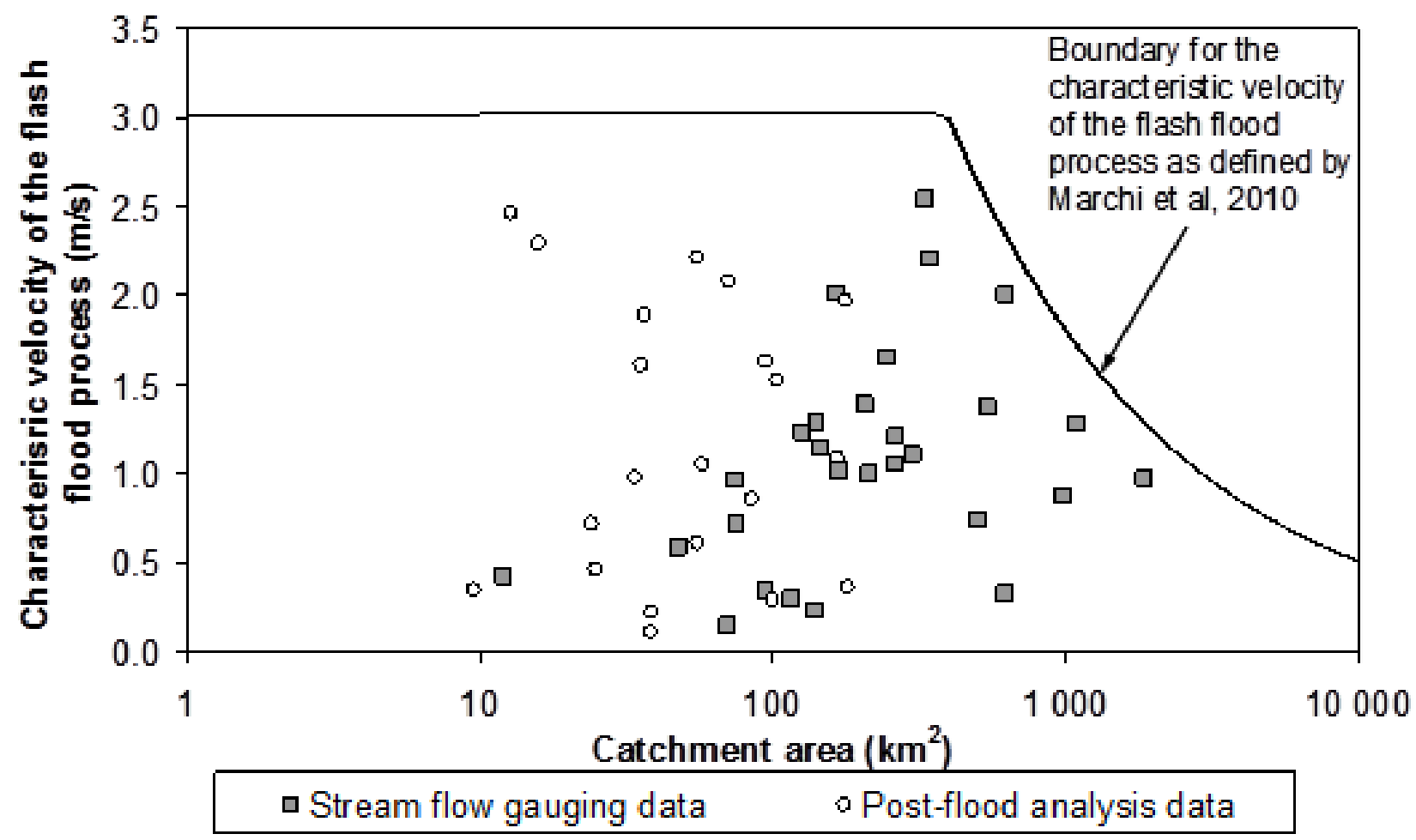

(Based on data collected by Marchi et al, 2010)

Figure 6: Characteristic velocity of the flash flood process

Although the "characteristic velocity" of the flash flood process estimated by Marchi et al (2010) cannot be directly related to the mean cross-sectional velocity computed as part of an indirect flash flood estimate it does indicate that "high" velocities $(>3 \mathrm{~m} / \mathrm{s}$ ) are not the norm, even for extreme flood events such as these. Although we recognise that mean, peak, cross-sectional velocities during flash floods can in some cases exceed $3 \mathrm{~m} / \mathrm{s}$, where they do evidence needs to be collected from the field to substantiate it.

\subsubsection{The use of simple rainfall - runoff and routing models}

In many cases, although data are often limited, it is possible to carry out some form of rainfall - runoff modelling together with a hydrological routing model to validate estimates of flash flood flows that have been made using other indirect methods. Rainfall hyetographs can be constructed using observed rainfall data or calibrated radar data, if available.

In November 1999, over $500 \mathrm{~mm}$ of rainfall fell on the Aude region of France in two days resulting in extreme flash floods. Specific peak discharges of some of these flash floods exceeded $10 \mathrm{~m}^{3} / \mathrm{s} / \mathrm{km}^{2}$. Post flood surveys were carried out on the Tournissan Stream which drains a catchment of $10 \mathrm{~km}^{2}$. Using indirect methods the peak discharge was estimated to be $200 \mathrm{~m}^{3} / \mathrm{s}$ (i.e. $20 \mathrm{~m}^{3} / \mathrm{s} / \mathrm{km}^{2}$ ) (Gaume et al, 2004). This peak discharge had a return period in excess of 1 in 100 years. 
In order to provide another estimate of flood flows and to assess the timing of the flood wave a combined rainfall - runoff and routing model was constructed for the catchment. The semi-distributed rainfall-runoff model was based on the US Soil Conservation Service (SCS) Curve Number (CN) method together with a routing model based on a kinematic wave routine. CNs of 50,70 and 100 were used, where a CN of 100 represents $100 \%$ runoff from the catchment. Calibrated radar rainfall data were available to use as an input to the model (FLOODsite, 2006). Information was also collected independently from a number of local residents regarding the timing of the flood via a survey using open questions such as: "Tell us in detail what happened?" and "When and how fast did the water level rise?" (Gaume et al, 2004) This allowed the time when the river started to overflow its banks, as well as the time of the two peaks to be estimated independently of the rainfall-runoff and routing model.

The indirect peak flow estimates for this event ranged from $150 \mathrm{~m}^{3} / \mathrm{s}$ to $250 \mathrm{~m}^{3} / \mathrm{s}$ with a mean of $200 \mathrm{~m}^{3} / \mathrm{s}$. The independently collected witness statements in conjunction with the rainfall-runoff and routing model provided confidence that the time of travel of the flood wave had been estimated correctly and that roughness coefficients used in the indirect estimates were reasonable. Although there was a degree of uncertainty in the radar rainfall data used as an input, the rainfall-runoff model using a CN of 100 also helped to confirm that a peak discharge greater than $250 \mathrm{~m}^{3} / \mathrm{s}$ was very unlikely to have occurred and that the high estimated discharge values ( 15 to $20 \mathrm{~m}^{3} / \mathrm{s} / \mathrm{km}^{2}$ ) were consistent with the estimated rainfall rate. The model was also used to confirm times of travel estimated from witness statements and indirect peak discharge estimates at points further downstream on the same watercourse. In this way the rainfall-runoff and routing models help to provide a method to assess if there has been any obvious over estimates in the peak flash flood discharge and to provide confidence in the values of Manning's $n$ used. An example of this is shown in Figure 7. It is important to note that systematic checks of indirectly estimated peak flash flood discharges were made for the majority of the data that were collected as part of the HYDRATE project. These data were used to corroborate the reliability of the indirectly estimated peak flows and illustrate the importance of these techniques used in conjunction with evidence from local stakeholders in reducing the uncertainty in these estimates. It is important to note that witness statements of flood events need to be collected carefully and can contain erroneous statements. However, Gourley et al, 2010 have also shown that these statements can be useful when assessing flash flood flows. 


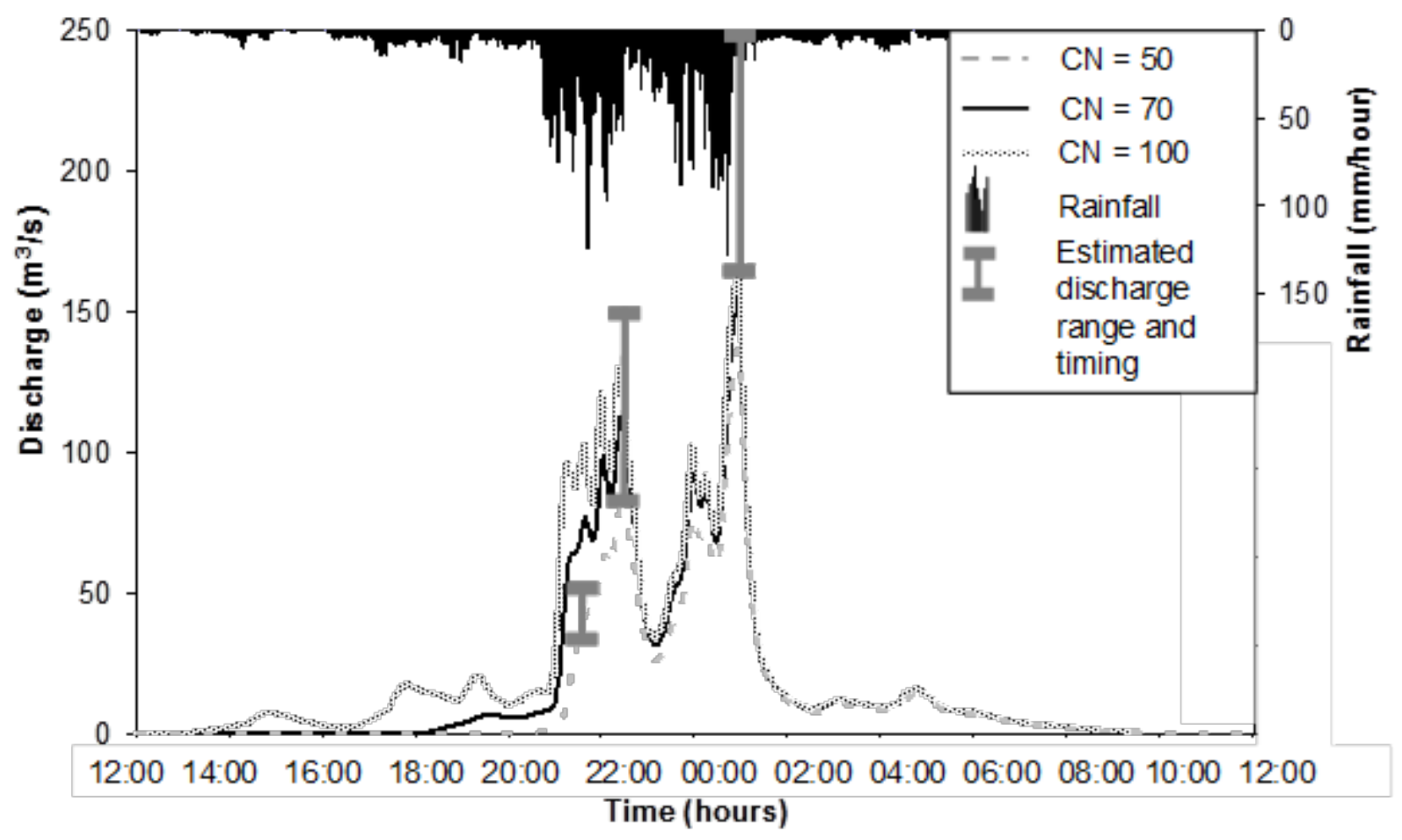

(Source: Gaume et al, 2004)

Figure 7: Comparison of estimated discharge using indirect methods with rainfall - runoff generated hydrographs for the Tournissan Stream, France for the November 1999 flood event

\subsection{Use of pictures and films of the flood event}

Photographs are often available of extreme flood events. These can be used to confirm mean velocity estimates, which are especially important where the mean velocity is estimated to have exceeded $3 \mathrm{~m} / \mathrm{s}$. Witnesses of flash floods tend to overestimate their velocity because turbulent water always seems to be flowing faster than tranquil water (Ledger, 1981).

Photographs will often show evidence of a sudden increase in the water surface in front of obstacles that can be used to estimate the velocity of the flow. This velocity head build up at an obstacle is linked to the flow velocity via Bernoulli's equation and the velocity estimated based on the hypothesises that the specific hydraulic head is homogeneous in the vicinity of the obstacle and that the water velocity just in front of the obstacle is equal, or close to zero. Using these assumptions an estimate of the flow velocity $v$ in $\mathrm{m} / \mathrm{s}$ can be calculated from:

$v=\sqrt{2 g \Delta h}$

Where $\mathrm{g}$ is acceleration due to gravity in $\mathrm{m} / \mathrm{s}^{2}$ and $\Delta h$ is the increase in water elevation in front of the obstacle in $\mathrm{m}$.

Although it recognised that estimates of velocity from estimates of velocity head build up can be very uncertain they can provide a means of validation where estimated mean velocities appear to be high (i.e. $>3$ 
$\mathrm{m} / \mathrm{s}$ ). For example a velocity of $3 \mathrm{~m} / \mathrm{s}$ generates a velocity head build up of $0.46 \mathrm{~m}$, whilst a velocity of $6 \mathrm{~m} / \mathrm{s}$ would lead to one of $1.83 \mathrm{~m}$. Often videos taken by local residents can also be used to confirm flood flow velocities estimated from using indirect methods. On 18 September 2007, there was widespread flash flooding from the Selščica Sora River at the town of Železniki in Slovenia. Shortly after the event a post flood survey was carried out that included surveys of cross sections, the river bed slope, flood mark levels, as well as interviews with eye witnesses.

During the peak of the flood a local resident made a video recording of the event. Stills from this video are shown in Figure 8. The velocity was estimated from the time it took a piece of floating debris visible on the video to pass between two landmarks, a lamp post and a fence, a known distance apart. This basic analysis found that the water surface velocity was approximately $3 \mathrm{~m} / \mathrm{s}$. In this case stills from the video could also be used to estimate the velocity by measuring the velocity head build up at a lamp post and a fence post on image, shown in Figure 8. The estimates of the velocity head build up at these obstacles give a result of around $3 \mathrm{~m} / \mathrm{s}$, which is consistent with the video analysis.
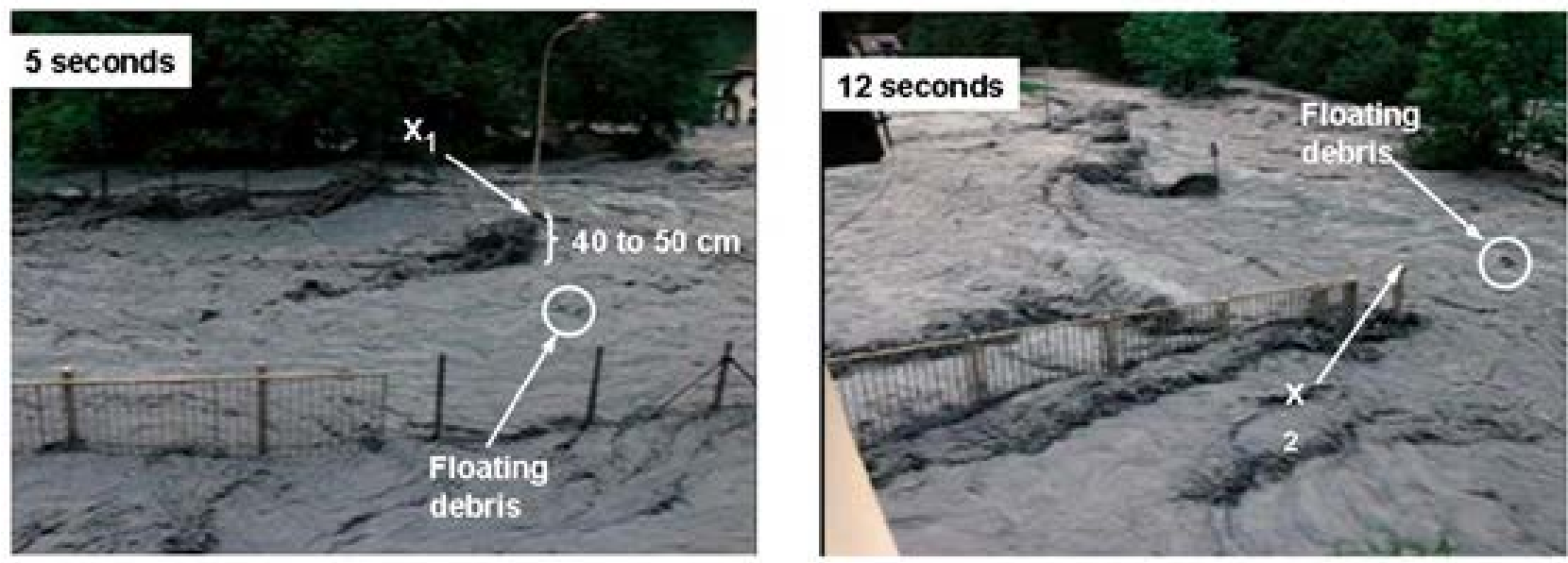

\section{Distance between the points $X_{1}$ and $X_{2}$ is 21 metres}

Time of travel between the points $X_{1}$ and $X_{2}$ of the floating debris shown was 7 seconds

Figure 8: Stills from video film used to estimate velocities for the Selščica Sora River, at Železniki, Slovenia taken during the peak of the flood in September 2007

\subsection{Estimation of the mean Froude number}

During flash flood large quantities of energy are dissipated as the result of turbulence, expansion and contraction, scour, deposition and other factors shown in Figure 1. These energy losses will generally keep the average velocity for a reach subcritical and the Froude number below one. Studies and research by Dobbie and Wolf (1953), Jarrett (1984, 1987), Trieste and Jarrett (1987), Grant (1997) and Tinkler (1997) have indicated that super-critical flows do not occur in most natural high-gradient channels over long reaches (i.e. $>20 \mathrm{~m}$ in length), even in the case of flood waves caused by dam breaks such as those studied by Blanton (1977), Fread (1977), Jarrett (1984), Trieste (1992) and Yochum et al (2008).

Trieste (1992) argues that as discharge increases so do energy losses and because these have been lumped into Manning's $\mathrm{n}$, the $\mathrm{n}$ value needs to be increased to take this into account. Trieste (1992) 
indicated that for large observed floods field selected values of Manning's $\mathrm{n}$ based on the guidance documents described in this paper were in some cases too low by a factor of just over two.

The research carried out indicates that if the average Froude number for a cross-section used in an indirect flood flow estimate is found to be significantly greater than one (i.e. $\mathrm{Fr}>1.3$ ) then it is likely that the Manning's $n$ roughness coefficient has been underestimated. The Froude number is given by:

$$
\operatorname{Fr}=\frac{v}{\sqrt{d g}}
$$

Where $\mathrm{v}$ is the mean cross-sectional velocity; $\mathrm{g}$ is the acceleration due gravity in $\mathrm{m} / \mathrm{s}^{2}$ and $\mathrm{d}$ is the mean depth in $\mathrm{m}$.

Critical flow is normally defined by $\mathrm{Fr}=1$, setting the Froude number to one and substituting into Manning's formula (Equation 2) the Manning's ( $n_{\text {crit }}$ ) for a mean Froude number of one across the cross-section is given by:

$$
n_{c r i t}=R^{\frac{2}{3}} \sqrt{\frac{S_{f}}{g d}}
$$

Where $\mathrm{R}$ is the hydraulic radius in $\mathrm{m} ; \mathrm{S}_{\mathrm{f}}$ is the slope in $\mathrm{m} / \mathrm{m}$.

If when carrying out the validation steps discussed above the mean Froude number, Fr, for the estimates are found to be significantly greater than one (i.e. $\mathrm{Fr}>1.3$ ), a first estimate of Manning's $\mathrm{n}$ could be made using Equation 11. It should be recognised that the Manning's $n$ generated by equation 11 could represent a lower limit of the roughness with the actual value of the roughness possibly being considerably higher, as Trieste found when carrying a hydraulic analysis of the flash flood that resulted from the Quail Creek Dam failure in Utah that occurred on 1 January 1989 (Trieste, 1992).

\section{Case study - The Rubí Torrent, September 1962 flood, Spain}

On 25 September 1962 an extraordinary flood took place in a dry river bed known as the Riera de Rubí or the Rubí Torrent in the municipality of Rubí upstream of Barcelona, Spain. The flood resulted in between 800 and 900 deaths (López Bustos et al, 1964). The Rubí Torrent has a slope of $0.0325 \mathrm{~m} / \mathrm{m}$ and drains an area of approximately $24.3 \mathrm{~km}^{2}$ (López Bustos et al, 1964). The Rubí Torrent is confined to an engineered, trapezoidal channel in the vicinity of the municipality of Rubí as shown in Figure 9. Over the past 45 years a number of estimates of the peak flood flow have been made using indirect methods.

Initial estimates of the peak flow made in the 1960s by the Madrid Hydraulic Institute using the slope - area method using the cross-sections shown in Figure 10, with Manning's n of 0.020 , based on guidance document data, led to an estimated peak discharge of 1,750 $\mathrm{m}^{3} / \mathrm{s}$ (López Bustos et al, 1964). The site was revisited by the HYDRATE project team in 2008 . The peak flow of $1,750 \mathrm{~m}^{3} / \mathrm{s}$ appeared to have been overestimated. The evidence to support this opinion was based on the following:

1. The catchment has an estimated time of concentration of approximately one hour. A peak flow of 1,750 $\mathrm{m} 3 / \mathrm{s}$ would require a rainfall intensity of $259 \mathrm{~mm} /$ hour over the whole catchment. However, estimates of the maximum rainfall intensity for event are between 140 and $180 \mathrm{~mm}$ within three hours (López Bustos et al, 1964) 
2. A simple SCS rainfall - runoff model where the assumptions were made that $180 \mathrm{~mm}$ of rain fell in one hour, the Curve Number was 100 (i.e. the catchment was 100\% impermeable) and there were no initial losses yielded a peak flow of approximately $1,000 \mathrm{~m}^{3} / \mathrm{s}$. This indicates that the original flow estimate of $1,750 \mathrm{~m}^{3} / \mathrm{s}$ is probably too high. Information given in Barrera et al's review of extreme flash floods in the vicinity of Barcelona (Barrera et al, 2006) also suggest that the assumptions made regarding the parameters in the SCS rainfall - runoff for Rubí Torrent catchment were conservatively high

3. The envelope for the world's maximum observed floods (Herschy, 2002; IAHS, 2003) yields a maximum specific discharge of $53 \mathrm{~m}^{3} / \mathrm{s} / \mathrm{km}^{2}$ for a catchment of this size. The estimate made by López Bustos et al gives a specific discharge almost $50 \%$ higher

4. The peak mean cross-section velocity for the initial estimates was between $11 \mathrm{~m} / \mathrm{s}$ and $17 \mathrm{~m} / \mathrm{s}$

5. The mean Froude number was estimated to be 3.5 over a reach of several hundred metres

Using revised estimates of water levels that took into account re-estimated maximum flood levels and a Manning's $n$ of 0.05 the flood flow on 25 September 1962 was re-estimated to be around $650 \mathrm{~m}^{3} / \mathrm{s}$ and the mean section velocity to be about $6 \mathrm{~m} / \mathrm{s}$ and a mean Froude number of approximately 0.9 (HYDRATE, 2008). There is a degree of uncertainty in this estimate; however, based on the value of Manning's $n$ and the maximum water levels used the peak flow is likely to be between $500 \mathrm{~m}^{3} / \mathrm{s}$ and $800 \mathrm{~m}^{3} / \mathrm{s}$. The velocity and Froude number could have been as high as $8 \mathrm{~m} / \mathrm{s}$ and 1.1 respectively. However, these flow estimates appear to be "more realistic" than the previous value of $1,750 \mathrm{~m}^{3} / \mathrm{s}$. 


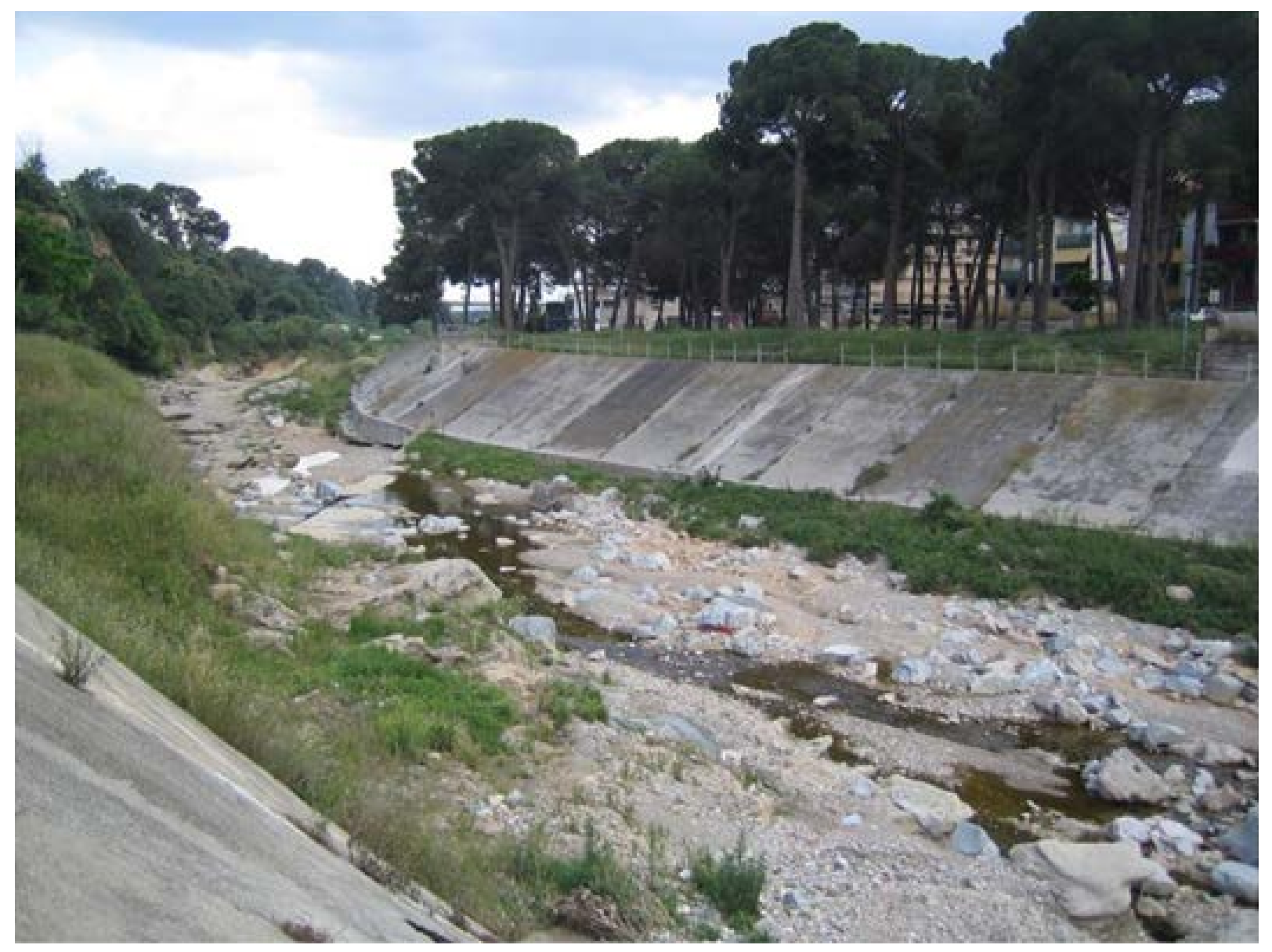

Figure 9: A typical view of the Rubí Torrent taken in 2008 

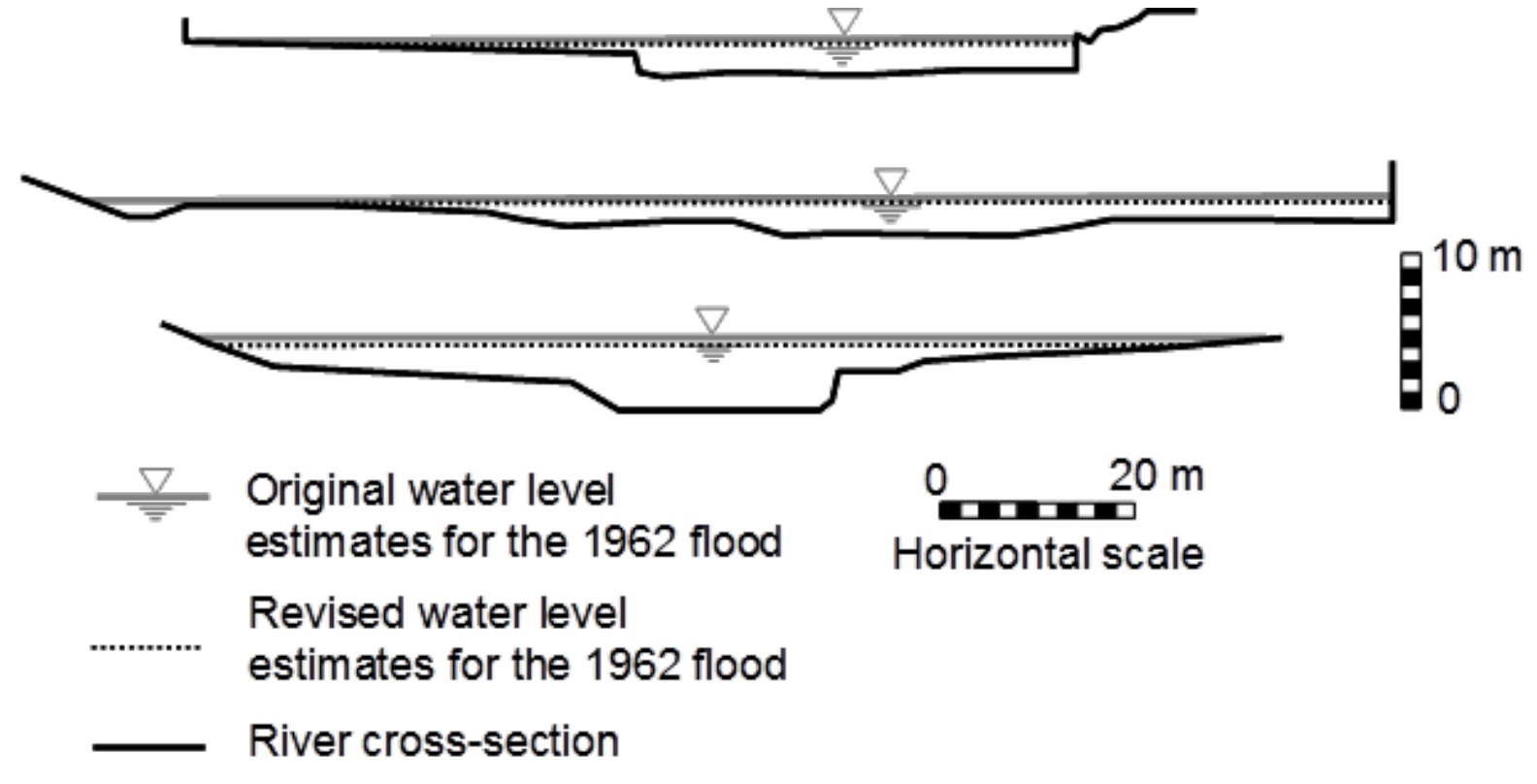

(Source: López Bustos et al, 1964)

Figure 10: Cross-sections of the Rubí Torrent used in the indirect discharge estimates

\section{Discussion}

Indirect measurements of peak flash flood discharges play an important part in adding to the hydrological knowledge of these events. When estimating flood discharges indirectly one of the greatest difficulty lies in the estimation of Manning's roughness coefficient $n$ as there is no exact method for determining all its constituent components (see Figure 1). There is a degree of subjectivity in estimating Manning's $n$ especially for extreme flood flows.

Costa and Jarrett (2008) recently revaluated the top 30 US extraordinary floods. Only two of the floods in US top 30 were measured using a current meter. Their recent re-analysis of the estimation of extreme flood discharge in the USA has led to significant decreases in the estimated discharges of some of the largest reported flash floods mainly as a result of revised estimates of either Manning's $n$ or mean flow velocities that have been used in the estimates (House and Pearthree, 1995; Jarrett, 1987) indicating that the uncertainty in these estimates is large often of the order of $\pm 50 \%$ to $\pm 100 \%$ rather than the often quoted $\pm 10 \%$.

The mean cross-sectional Froude numbers for the 19 US extraordinary floods detailed in Costa and Jarrett (2008) vary from 0.60 to 2.75 with nine of the 19 floods having estimated Froude numbers in excess of one (i.e. the flow was estimated to be supercritical over a long reach of the watercourse). The assumption of Froude numbers greater than one and supercritical flow over long reaches of natural channels by Costa and Jarrett may have led to underestimates of roughness resulting in overestimates of velocities and peak discharges.

Figure 11 shows distributions of velocities for the US extraordinary floods; HYDRATE floods; and the various guidance documents as detailed in Figure 2. An additional velocity distribution has been added to show the velocity distribution of the US extraordinary floods where if $\mathrm{Fr}>1$ the velocity has been re-estimated assume 
$\mathrm{Fr}=1$. Figure 11 shows that the revised distribution of mean velocities reduces significantly and indicates that some of the extraordinary peak flood discharges may have been overestimated.

Figure 12 shows the distributions of Manning's $n$ values for the US extraordinary floods; HYDRATE floods in France and Slovenia; and various guidance documents as detailed in Figure 3. An additional distribution has been added to showing the US extraordinary floods Manning's $n$ distribution where if $F r>1$ Mannings $n$ has been set to $\mathrm{n}_{\text {crit }}$ as defined by equation 11 .

Figures 3 and 12 show that generally the Manning's $n$ used to estimate the US extraordinary flood peak discharges are less than those used in various guidance documents. This is somewhat unexpected given that the guidance document Manning's $\mathrm{n}$ distribution is mainly based on tranquil flows, that are generally less than bankfull, mainly measured in regular, alluvial bed, drainage channels. Given the multitude of factors that influence roughness during an extraordinary flood and that must be incorporated into Manning's $n$, shown in Figure 1, it could be expected that the 25, 50 and 75 percentile values of the US extraordinary floods Manning $n$ distribution should be higher not lower than the guidance document distribution. The recalculation of this distribution by using $n_{\text {crit }}$ (Equation 11) to estimate Manning's $n$ where the mean crosssectional Froude number was initially estimated to be greater than one produces what could be argued, given the evidence presented in this paper, to be a more "realistic" roughness distribution for US extraordinary floods.

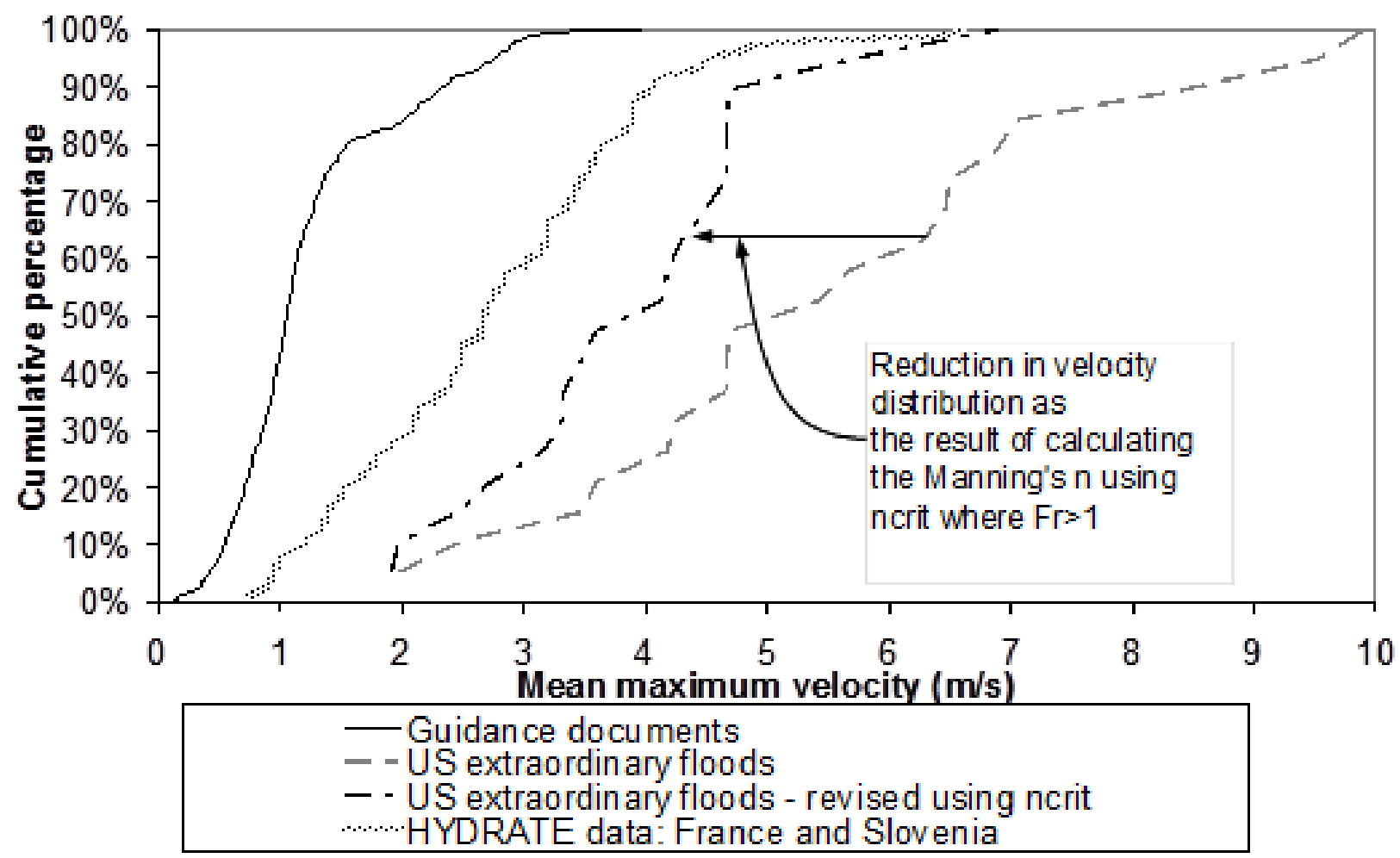

(Sources of data: Barnes, 1967; Chow, 1959; Cone et al, 1914; Costa and Jarrett, 2008; Environment Agenoy, 2002; Fasken, 1963; HYDRATE 2008; Land and Water Australia, 2009; Ramser, 1929; Scobey, 1939; Soong, 2009; Spreafico et al, 2001)

Photograph 11: Distribution of the mean maximum flood flow velocity for extraordinary floods in the USA; France and Slovenia; for a range of guidance documents compared with a revised distribution for the USA assuming Manning's n = ncrit 


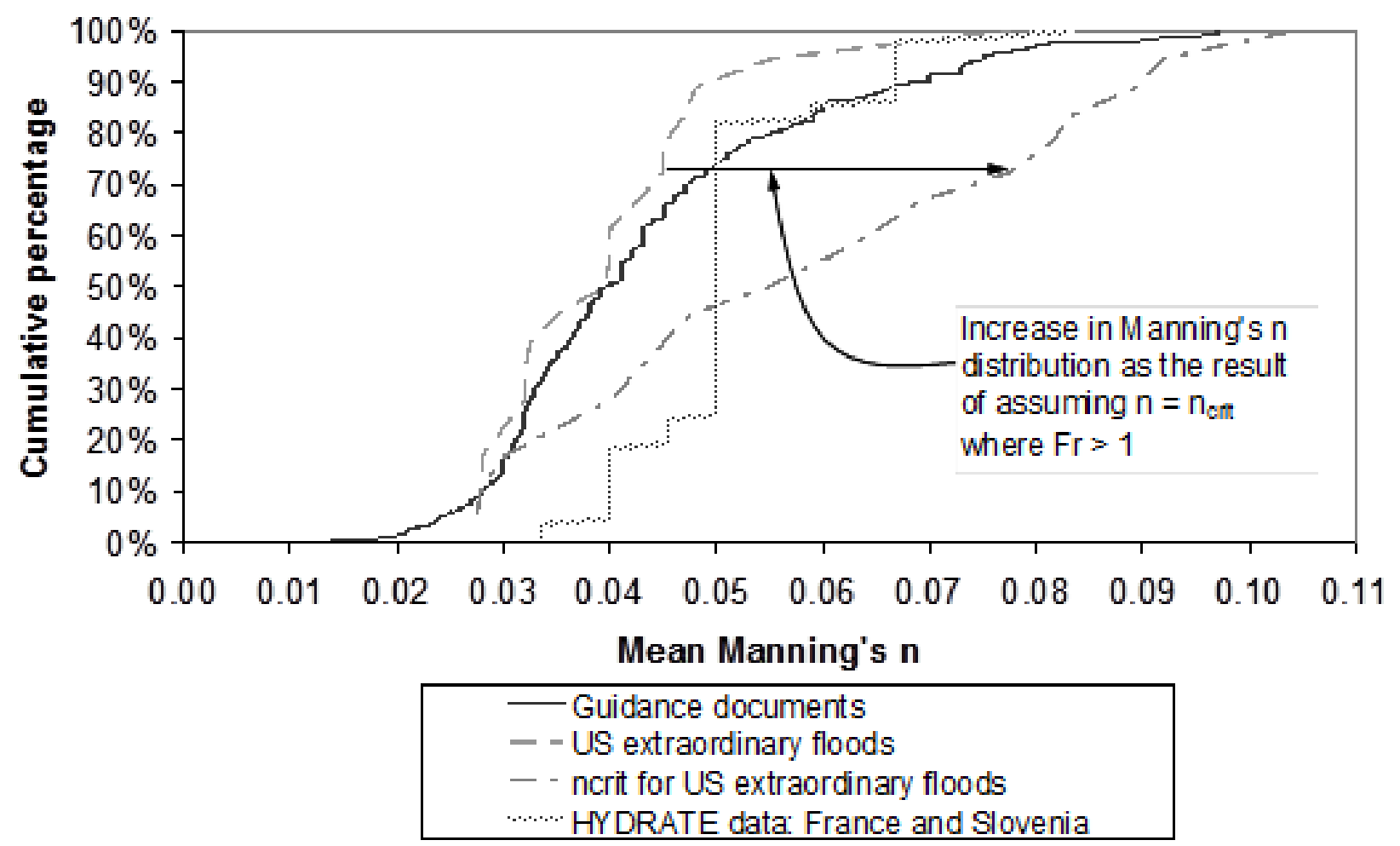

(Sources of data: Barnes, 1967; Chow, 1959; Cone et al, 1914; Costa and Jarrett, 2008; Environment Agenoy, 2002; Fasken, 1963; HYDRATE 2008; Land and Water Austalia, 2009; Ramser, 1929; Scobey, 1939; Scong, 2009, Spreafico et al, 2001)

Photograph 12: Distribution of the mean Manning's n and ncrit for extraordinary floods in the USA; France and Slovenia; and for a range of guidance documents

Using the revised values of mean velocity calculated assuming Manning's $n=n_{\text {crit }}$ when the mean Froude number is greater than one, the US extraordinary flood peak discharges have been recalculated. The changes in these discharges are shown in Figure 13 together peak flash flood flow discharges from a number of European extraordinary floods (HYDRATE, 2008) and data from the World Catalogue of Maximum Observed Floods (IAHS, 2003). Figure 13 also shows the maximum envelope curve for unit discharge per unit area of catchment, $Q_{u}$, as defined by Herschy (2002) and the IAHS (2003). It is important to note that five of the eight maximum observed floods that inform the curve for catchments less than approximately $100 \mathrm{~km}^{2}$ were "observed" in the USA. The revision to the US extraordinary flood values and the fact that many of these values have been revised calls for reconsideration of this envelope for catchments with areas of less than $100 \mathrm{~km}^{2}$. 


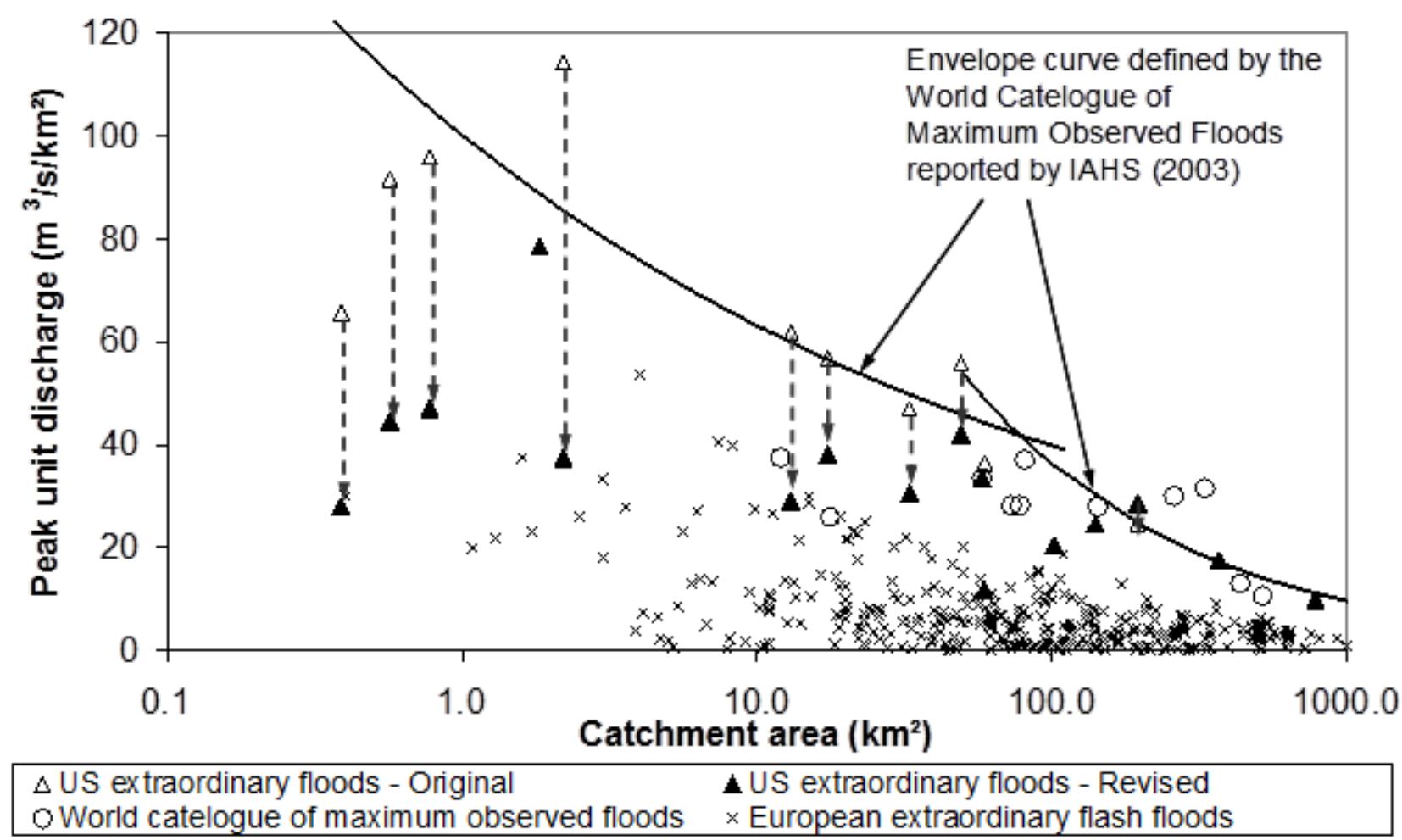

(Sources of data: Costa and Jarrett, 2008; Gaume et al, 2009; Herschy, 2002; IAHS, 2003; HYDRATE, 2008; Marchi et al, 2010)

\section{Figure 13: Implications of the findings on the World Maximum Observed Flood envelope}

It should be noted that the peak discharges of European floods were also be revised assuming that $\mathrm{Fr}=1$. However this revision of the European flash flood data does not influence the World Catalogue of Maximum Observed Floods' envelope because only around 10\% of the European floods had a Fr>1 and most of their peak discharges lay well below the world envelope even before revising them by using $\mathrm{n}_{\text {crit. }}$.

The work carried out also has implications for paleoflood estimates. There are many paleoflood estimates where claims are made of mean velocities of up to $45 \mathrm{~m} / \mathrm{s}$ (Gornitz, 2009 and others). Even in the case of natural dam breaks such high velocities often along long reaches of rivers would appear unlikely and it would appear that this is because roughness coefficients are underestimate resulting in paleoflood peak discharges some times being overestimated. The implications for paleoflood estimates should only apply to those of a magnitude comparable to the flash floods covered in this work.

Figure 14 provides guidance for carrying out indirect estimates of extreme flood flows. It should be recognised that the guidance should not be followed blindly. However, it is important that practitioners can provide evidence that their extreme flood flow estimates are within physically accepted limits. This guidance aids this process. 


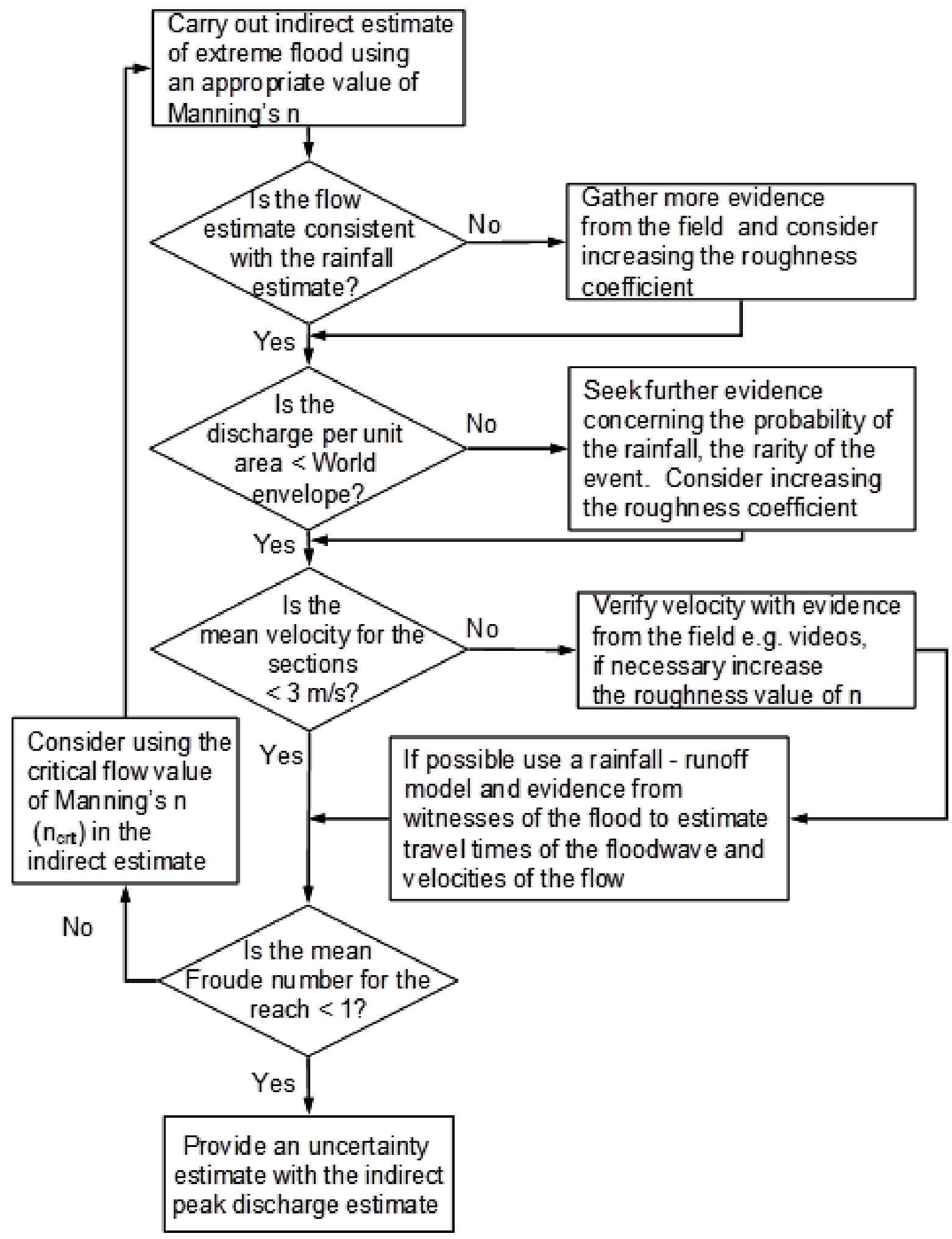

Photograph 14: Guidance for the estimation of extreme flood flows using indirect methods 


\section{Conclusions}

A review of the literature indicates that many hydrological and hydraulic analyses underestimate flash flood depths and overestimate flood velocities because Manning's n values, based on current guidance documents are too small. Selection of Manning's $\mathrm{n}$ still remains as much an art as a science. This paper has shown that an informed selection of roughness coefficient, often Manning's $n$, is a critical problem in determining flood discharges and may be one of the largest sources of uncertainty in indirect estimates (Costa, 1987; Jarrett, 1994). It is important that the uncertainty in the roughness coefficient is recognised by practitioners.

When assessing peak flash flood discharges using indirect methods it is important to carry out qualitative and quantitative analyses of site specific and regional hydrological, meteorological and other data, as well as employing a range of methods to support the estimates. The uncertainty in the estimates of peak flash flood discharges should be recognised. It is crucial that uncertainty in the peak flash flood flow estimates is not underestimated because in many cases the peak flood flash discharges are used to develop regional flood flow envelopes or flood frequency analyses.

Where indirect methods are used the maximum, mean velocity for the section, as well as the discharge should be calculated. Where maximum, mean velocities in a cross-section are found to be high (i.e. $>3 \mathrm{~m} / \mathrm{s}$ ), it is first necessary to properly identify the flow process. The mechanics of water floods and debris flow are fundamentally different; magnitudes cannot be estimated in the same manner. Debris flows will generally have significantly higher mean velocities than water floods. It is important to note that in some cases (e.g. relatively low slopes where alluvial fans are formed) debris flows can have mean velocities of $2 \mathrm{~m} / \mathrm{s}$ to $3 \mathrm{~m} / \mathrm{s}$, similar to flood flows. This illustrates the importance of field visits, photographs and video evidence to assess the morphological features of the channels and characteristics of the sediment deposits, as this can also be helpful in discriminating debris flows from water floods as stressed in the USGS guidelines (USGS, 2005). Assuming that it can be established that the flood flow is Newtonian, supporting evidence should be sought to confirm the estimated range of velocities. This can be estimates of the velocity head build up at obstacles or video evidence.

The mean cross-sectional Froude number should be estimated. Mean Froude numbers greater than one are highly unlikely to occur over long reaches, even in the case of dam breaks. Where the mean cross-sectional Froude number is greater than one at several cross-sections used in an indirect flow estimate it is recommended that the Manning's $n\left(n_{\text {crit }}\right)$ related to an average Froude number of one is used as an initial estimate of the roughness. However, it is important that other evidence is sought both from the field and in terms of rainfall-runoff modelling as the actual roughness value may be significantly higher than $\mathrm{n}_{\text {crit. }}$.

Practitioners need to be able to ascertain if the use of extreme values are warranted in such analyses and at the very least have a clear idea of the true uncertainty, especially in cases where the peak flood flow estimates are based on indirect methods using data collected several years after the event has taken place. The examples described in this paper illustrate that even when considerable field data are collected shortly after an event, uncertainties in peak flow estimates remain high (i.e. approximately $\pm 50 \%$ ). Quoted uncertainties of $\pm 10 \%$ for extreme flood flows estimated using indirect methods should be treated with caution.

Estimates of peak flash flood flows made from indirect methods applied on watercourses with gradients greater than $1 \%$ frequently have a high degree of uncertainty, often greater than $\pm 25 \%$. The estimation of Manning's roughness purely by visual means may be the single largest source of uncertainty in these computations. Alternative methods are needed to improve the accuracy of indirect discharge measurements. 
To conclude it is important to cast a critical eye over estimates of peak flash flood flows generated by indirect methods, especially where velocities or specific peak discharges are high, and to seek out as much verification data from the field as possible to gain a good understanding of the uncertainties.

\section{Acknowledgements}

Part of the research presented in this paper has been carried out using data from the European Commission Sixth Framework project HYDRATE. We would also like to express our thanks to the reviewers for their comments. This work would not have been possible without the Royal Academy of Engineers (RAEng) who provided a Global Research award to one of the authors. We wish to extend our thanks to the RAEng for their support.

\section{References}

Aldridge, B. N., 1978. Unusual hydraulic phenomena of flash floods in Arizona in Conference on Flash Floods - Hydrometeorological Aspects pp 117-120 American Meteorological Society, Boston 1978.

Arattano, M., Marchi, L., 2005. Measurements of debris flow velocity through cross-correlation of instrumentation data, Natural Hazards and Earth System Sciences (2005) 5: 137-142.

Arcement Jr, G.J., Schneider, V.R. 1989. Guide for selecting Manning's roughness coefficients for natural channels and floodplains US Geological Survey Water-Supply Paper 2339, p38.

Baker, V.R., Costa, J.E., 1987. Flood power in catastrophic flooding edited by L. Mayer and D. Nash pp 1-21 Allen and Unwin, Winchester, Mass, USA 1987.

Barnes, H., Bogart, D. (1961) Floods of September 6, 1960, in Eastern Puerto Rico, Geological Survey Circular 451, US Geological Survey, Washington DC, USA

Barnes, H., 1967. Roughness characteristics of natural channels, US Geological Survey, Water Supply Paper 1849, Washington, USA.

Barredo, J.I., 2007. Major flood disasters in Europe: 1950-2005, Journal of Natural Hazards, 42 (1), 125-148.

Barrera, A., Llasat, M. C., Barriendos, M. 2006. Estimation of extreme flash flood evolution in Barcelona County from 1351 to 2005 Natural Hazards and Earth System Sciences Vol pp 505-518

Bathurst, J.C., Li, R-M., Simons, D.B., 1979. Hydraulics of mountain rivers Report No. CER78-79JCB-RMLDBS55, Civil Engineering Department, Colorado State University, Fort Collins, Colorado, USA.

Benson, M.A., Dalrymple, T., 1967. Measurement of peak discharge by the slope-area method: U.S. Geological Survey Techniques of Water-Resources Investigations, Chap. A2, Book 3,

Blanton, J.O., 1977. Flood plain inundation caused by dam failure, in Dam break flood model workshop proceedings, Bethseda, MD, US Water Resources Council, Task Force on dam break flood routing, October 1977.

Borga, M., Gaume, E., Creutin, J-D., Marchi, L., 2008. Surveying flash floods: Gauging the ungauged extremes, Hydrological Processes, Volume 22, Issue 18, pages 3883-3885, 30 August 2008.

California Department of Transportation, 2009. Highway design manual

Centre for Ecology and Hydrology (CEH), 1999. Flood Estimation Handbook, ISBN: 9781906698003. 
Chow, V. T. 1959. Open channel hydraulics, McGraw Hill, New York.

Cone, V.M., Trimble, R. E., Jones, P. S., 1914. Fictional resistance in artificial waterways, Bulletin 194, The Agricultural Experiment Station of the Colerado College, January 1914.

Coon, W.F., 1998. Estimation of roughness coefficients for natural stream channels with vegetated banks US Geological Survey Water-Supply Paper 2441, 133p.

Costa J.E., 1987. A comparison of the largest rainfall - runoff floods in the United States with those of the people's Republic of China and the world. Journal of Hydrology 1987b, 96, 101-115.

Costa, J.E., 1988, Rheologic, geomorphic and sedimentologic differentiation of water floods, hyperconcentrated flows, and debris flows, in Baker, V.R., Kochel, R.C., and Patten, P.C. (eds) Flood Geomorphology: Wiley-Intersciences, New York, pp113-122

Costa, J.E., Jarrett, R.D., 2008. An evaluation of selected extraordinary floods in the United States reported by the U.S. Geological Survey and implications for future advancement of flood science: U.S. Geological Survey Scientific Investigations Report 2008-5164, 232 p.

Dobbie, C.H., Wolf, P.O., 1953. The Lynmouth flood of August 1952 Proceedings of the Institution of Civil Engineers Vol 2 pp522-88

Dingman, S.L., 2008. Physical hydrology Edition 2 published by Waveland Press, Inc.

Environment Agency, 2002. Measured flow data collected by the National Rivers of England and Wales between 1985 and 1992 for six gauging stations on the River Severn.

Farquharson, F.A.K., Meigh, J.R., Sutcliffe, J.V. 1992. Regional flood frequency analysis in arid and semiarid areas, Journal of Hydrology Volume 138, Issues 3-4, October 1992, pp 487-501.

Fasken, G.B., 1963. Guide for selecting roughness coefficient "n" values for channels US Department of Agriculture, Soil Conservation Service, Lincoln, Nebraska, 24 p plus appendixes.

Fischenich, C., 2000. Robert Manning - A historical perspective, Ecosystem Management and Restoration Research Program Technical Notes Collection, US Army Engineer Research and Development Center, Vicksburg, USA.

Fisher, K., Dawson, H., 2003. Reducing uncertainty in river flood conveyance - Roughness review - Project W5A - 057 - DEFRA/Environment Agency.

FLOODsite, 2006. Post flash-flood investigations - Methodological Note, March 2006 Available at http://www.floodsite.net/html/publications2.asp?documentType=1\&Submit=View

Fread, D.L., 1977. The development and testing of a dam break flood forecasting model in dam break flood model workshop proceedings, Bethseda, MD, US Water Resources Council, Task Force on dam break flood routing, October 1977.

Fukami, K., Yamaguchi, T., Imamura, H., Tashiro, Y., 2008. Current status of river discharge observation using non-contact current meter for operational use in Japan, World Environmental and Water Resources Congress 2008 Ahupua'a.

Gaume, E., Livet, M., Desbordes, M., Villeneuve, J-P., 2004. Hydrological analysis of the river Aude, France, flash flood on 12 and 13 November 1999 Journal of Hydrology Volume 286, Issues 1-4, 30 January 2004 , Pages 135-154. 
Gaume, E., Borga, M. 2008. Post-flood field investigations in upland catchments after major flash floods: proposal of a methodology and illustrations, Journal of Flood Risk Management 1 (2008) pp175-189.

Gaume, E., Bain, V., Bernardara, P., Newinger, O., Barbuc, M., Bateman, A., Blaškovicová, L., Blöschl, G., Borga, M., Dumitrescu, A., Daliakopoulos, I., Garcia, J., Irimescu, A., Kohnova, S., Koutroulis, A., Marchi, L., Matreata, S., Medina, V., Preciso, E., Sempere-Torres, D., Stancalie, G., Szolgay, J., Tsanis, I., Velasco, D., Viglione, A., 2009. A compilation of data on European flash floods, Journal of Hydrology 367 (1-2), 70-78.

Georgakakos, K.P., 1986. On the design of national, real-time warning systems with capability for sitespecific, flash-flood forecasts. Bulletin of the American Meteorological Society 67 (10), 1233-1239

Gillen, D.F., 1996. Determination of roughness coefficients for streams in West-Central Florida US Geological Survey Open-File Report 96-226

Golding, B., 2005. Meteorology of the Boscastle flood, Irish National Hydrology Seminar 2005.

Gornitz, V., 2009 Encyclopedia of paleoclimatology and ancient environments, published by Springer.

Grant, G.E., 1997. Critical flow constrains flow hydraulics in mobile-bed streams: A new hypothesis Water Resources Research, Vol 33, No. 2, pp 349-358, February 1997.

Gourley, J.J., Erlingis, J.M., Smith, T.M., Ortega, K.L., Hong, Y. 2010. Remote collection and analysis of witness reports on flash floods, Journal of Hydrology, Volume 394, Issues 1-2, 17 November 2010, pp53-62 Herschy, R.W., 2002. The world's maximum observed floods, Flow Measurement and Instrumentation 13 (2002) pp231-235.

Hicks, D.M., Mason, P.D., 1998. Roughness characteristics of New Zealand rivers 2nd edition by Water Resources Publications.

House, P.K., Pearthree, P.A., 1995. A geomorphic and hydrologic evaluation of an extraordinary flood discharge estimate: Bronco Creek, Arizona Water Resources Research Vol. 31 pp 3059-3073 December 1995.

HYDRATE, 2008. Collation of primary flash flood data, HYDRATE WP1 report, April 2008.

HYDRATE, 2010. HYDRATE Hydrometeorological data resources and technologies for effective flash flood forecasting home page http://www.hydrate.tesaf.unipd.it/

International Association of Hydrological Sciences (IAHS), 2003. World Catalogue of Maximum Observed Floods, IAHS Press.

James, P., Stohl, A., Spichtinger, N., Eckhardt, S., Forster, C., 2004. Climatological aspects of the extreme European rainfall of August 2002 and a trajectory method for estimating the associated evaporative source regions, Natural Hazards and Earth System Sciences 4 (5-6), pp733-746.

Jarrett, R.D., 1984. Hydraulics of high-gradient streams Journal of Hydraulic Engineering ASCE, 110(11), 1519-1539.

Jarrett, R.D., 1985. Determination of roughness coefficient in for streams in Colorado, US Geological Survey, Water Resources Investigations Report 85-4004, 54 p.

Jarrett, R.D., 1987. Errors in slope-area computation of peak discharges in mountain streams, Journal of Hydrology Volume 96, Issues 1-4, 15 December 1987, Pages 53-67 Analysis of Extraordinary Flood Events 
Julien, P.Y., Paris, A., 2010. Mean velocity of mudflows and debris flows, Journal of Hydraulic. Engineering, Volume 136, Issue 9, pp. 676-679, September 2010.

Knight, D.W., McGahey, C., Lamb, R., Samuels, P.G., 2010. Practical channel hydraulics: Roughness, conveyance and afflux, published by Taylor and Francis Press Group, ISBN 978-0-415-54974-5.

Knocke, E.T., Kolivras, K.N. 2007. Flash flood awareness in South-West Virginia, Risk Analysis, Volume 27, Issue 1, pages 155-169, February 2007

Land and Water Australia, 2009. An Australian handbook of stream roughness coefficients, Land and Water Australia, May 2009.

Ledger, D., 1981. The velocity of the River Tweed and its tributaries, Freshwater Biology vol 11 pp1-10.

Limerinos, J.T., 1970. Determination of the Manning coefficient from measured bed roughness in natural channels - Geological survey water supply paper 1898-B, United States Government Printing Office, Washington, 1970.

López Bustos, A., Coll, J.M., Llansó, J.M., Espinosa R., 1964. Resumen y conclusiones de los estudios sobre las avenidas del Vallés en 1962. Instituto de Hidrología, Madrid 1964.

Manning, R., 1891. On the flow of water in open channels and pipes, Transactions of the Institution of Civil Engineers of Ireland, 20, pp 161-207.

Marchi, L., Borga, M., Preciso, E., Gaume, E., 2010. Characterisation of selected extreme flash floods in Europe and implications for flood risk management, Journal of Hydrology, Volume 394, Issues 1-2, 17 November 2010, Pages 118-133.

Miklanek, P., Pekaraova, P., Konicek, A., Pekar, J., 2004. Research note: Use of a distributed erosion model (AGNPS) for planning small reservoirs in the Upper Torysa Basin Hydrology and Earth Science Systems 8(6), pp1186-1192 (2004).

Norbiato, D., Borga, M., Sangati, M., Zanon, F., 2007 Regional frequency analysis of extreme precipitation in the eastern Italian Alps and the August 29, 2003 flash flood Journal of Hydrology 345 (3-4), 149-166.

Phillips, J.V., Ingersoll, T.L., 1998. Verification of roughness coefficients for selected natural and constructed stream channel in Arizona, US Geological Survey Professional Paper 1584, 77p.

Prochaska, A.B., Santi, P.M., Higgins, J.D., Cannon, S.H., 2008. A study of methods to estimate debris flow velocity, Landslides, 2008, vol 5 pp 431-444.

Ramser, C.E., 1929. Flow of water in irrigation and similar canals, US Department of Agriculture, Technical Bulletin No 129, November 1929.

Roca, M., Davison, M. 2010. Two dimensional model analysis of flash flood processes: Application to the Boscastle event Journal of Flood Risk Management Volume 3 Issue 1, Pages 63 - 71.

Scobey, F.C., 1939. The flow of water in irrigation and similar canals, Technical Bulletin No. 652 February 1939, US Department of Agriculture, Washington DC.

Soong, D.T., Halfar, T.M., Wobig, L.A., 2009. Estimating Manning's roughness coefficients for natural and man-made streams in Illinois.

Soto, A.U., Madrid-Aris, M., 1994. Roughness coefficient in mountain rivers, American Society of Civil Engineering, Hydraulics Engineering, New York, August, 1994. 
Spreafico, M., Hodel, H.P., Kaspar, H., 2001 Rauheiten in ausgesuchten schweizerischen Fliessgewässern Berichte des BWG, Serie Wasser - Rapports de l'OFEG, Série Eaux - Rapporti dell'UFAEG, Serie Acque Nr 1. - Bern 2001.

Sutcliffe, J.V., 1978. Methods of flood estimation: a guide to the Flood Studies Report. Wallingford, Institute of Hydrology, 50pp. Institute of Hydrology Report No.49.

Tinkler, K.J., 1997. Critical flow in rock bed streams with estimated values for Manning's n Geomorphology 20147164.

Trieste, D.J., 1992. Evaluation of supercritical/subcritical flows in high-gradient channel, Journal of Hydraulic Engineering, Vol 118, No 8, August 1992.

Trieste, D.J., Jarrett, R.D., 1987. Roughness coefficients of large floods in Proceedings of Irrigation Systems for the 21st Century, Portland, Oregon 28 - 30 July 1987 pp 32-40

Ulbrich, U, Brücher, T., Fink, A.H., Leckebusch, G.C., Krüger, G., Pinto, J.G. 2003. The central European floods of August 2002: Part 1 - Rainfall periods and flood development, Weather Vol 58, October 2003 available at http://www.meteo.uni-koeln.de/content/downloads/weather part1.pdf

US Geological Survey (USGS), 2005. Distinguishing between debris flows and floods from field evidence in small watersheds, USGS Fact Sheet 2004-3142, January 2005.

Wahl, K.L., 1993. Variation of Froude number with discharge for large-gradient streams, in Hydraulic Engineering '93, edited by H.W. Shen, S. T. Su, and F. Wen., pp. 1517-1522, American Society of Civil Engineers, New York, 1993.

Webb, R.H., Jarrett, R.D., 2002. One-dimensional estimation techniques for discharges of paleofloods and historical floods in House, P.K., Webb, R.H., Baker, V.R., and Levish, D.R., eds., Ancient floods, modern hazards, principles and applications of paleoflood hydrology: American Geophysical Union Water Science and Application Series, v. 5, p. 111-125.

Whatmore, S., Landström, C., 2009. Manning's n - Putting roughness to work, in Morgan, M. and Howlett, P., How well do facts travel? Cambridge University Press, Cambridge.

Yochum, S.E., Goertz, L.A., Jones, P.H., 2008. Case study of the Big Bay Dam failure: Accuracy and comparison of breach predictions, Journal of Hydraulic Engineering ASCE, September 2008 